\title{
"Erkek" Olmak ya da Olmamak: Sosyal Psikolojik Açıdan Erkeksilik/Erkeklik Çalışmaları
}

\author{
Nuray Sakall \\ Orta Doğu Teknik Üniversitesi
}

\author{
Beril Türkoğlu
}

Ankara Medipol Üniversitesi

\begin{abstract}
Özet
Bu makalenin amacı yazında erkeksilik, erkeklik ve erkeklik stresi adı altında yapılan araştırmaları kalıpyargılar, tutumlar ve ayrımcılık ana başlıkları altında sosyal psikolojik açıdan sunmaktır. Bu bağlamda, ilk olarak, toplumsal cinsiyet kalıpyargıları çerçevesinde erkeksilik ve erkeksi kalıpyargılar hakkındaki çalışmalara yer verilmiştir. İkinci olarak, tutum seviyesinde ele alınan erkeklik ve erkeklik ideolojisi konusundaki çalışmalar, özellikle uluslararası yazında erkeksilik/erkeklikle ilgili tutumları farklı yaklaşımlarla ölçen ölçekler, bağlamında sunulmuştur. Ayrıca, erkeklik rollerine ve normlarına uy(a)mamanın yarattığı çelişki, stres ve gerginlik konusundaki ölçek çalışmalarına da değinilmiştir. Yazındaki bu tür korelasyonel çalışmalar, nitel çalışmalar ve ölçek geliştirme çalışmalarının yanı sıra erkeklik kavramını deneysel çalışmalarla test eden kırılgan erkeklik kuramı da sunulmuştur. Üçüncü olarak, erkekliğin, hem birey olarak erkeklere hem de diğerlerine verdiği zararlar ayrımcılık kapsamında bir araya toplanmıştır. Son olarak, Türkiye yazınında, özellikle sosyal psikoloji çalışmalarına odaklanılarak, erkeklik konusunu farklı bakış açılarıyla ele alan çalışmalar sunulmuş ve gelecek çalışmalar için önerilere yer verilmiştir. Ele alınan araştırmalara göre, betimsel erkeksi kalıpyargılar bir taraftan bilişsel kolaylıklar sunarken diğer yandan özellikle buyurgan ve yasaklayıcı kalıpyargılara uymayanlar cezalandırılmaktadır. Ayrıca, statü, kadınsılıktan uzak durma, sertlik, başarılı olma, duygularını saklama vb. gibi normatif özelliklerle ölçülen erkeklik normları, erkekler üzerinde bireysel baskılar ve problemler yaratmakta; erkekliklerine tehdit algıladıklarında (örn., kadınsı olduklarının belirtilmesi durumunda) erkekler kendilerine veya diğerlerine (örn., kadınlar ve geyler) zararlı olabilecek riskli davranışlar, şiddet ve öfke göstermektedirler. Tüm bu çalışmalar, erkek olmanın inşasındaki dinamikleri ve olumsuz toplumsal ve bireysel sonuçları açıklar niteliktedir.
\end{abstract}

Anahtar kelimeler: Erkeksilik, erkeklik, kırılgan erkeklik, cinsiyet rol stresi, kalıpyargılar, tutumlar

\begin{abstract}
The purpose of the current review is to present studies on masculinity, manhood, and masculine gender role stress under the main subtitles of gender stereotypes, attitudes, and discrimination from social psychological perspectives. First of all, from gender stereotype perspective, studies on masculinity and gender role stereotypes are presented. Secondly, masculine ideologies which have been examined at the attitudes and attitude measurement level, especially attitude scales measuring male role, masculine ideology or men are covered. Further, the scales about gender role stress are included. Then, precarious manhood theory, which tests manhood issues with experimental method, is explained. Thirdly, reflecting discrimination, destructive outputs of masculinity and manhood on men and others (such as women and gay men) are presented. Lastly, studies, especially social psychological research, on masculinity and manhood conducted in Turkey are introduced, and some future suggestions are given. According to the studies, prescriptive and proscriptive stereotypes have some backlash effect for those who transgress them while descriptive masculine stereotypes serve cognitive functions. Also, masculine norms and masculinity ideology which reflect the importance of status, antifemininity, toughness, non-emotionality, and achievement etc. create some individual and interpersonal problems. Men who feel that their masculinities are threatened may present risky, violent and aggressive behaviors towards themselves and others. All these studies show that the construction of masculinity/manhood may create some societal problems.
\end{abstract}

Keywords: Masculinity, manhood, precarious manhood, gender role stress, stereotypes, attitudes

Yazışma Adresi: Prof. Dr. Nuray Sakallı, Orta Doğu Teknik Üniversitesi, Fen-Edebiyat Fakültesi, Psikoloji Bölümü, Üniversiteler Mahallesi, Dumlupınar Bulvarı No:1 06800 Çankaya / Ankara

E-posta: nurays@metu.edu.tr

Gönderim Tarihi: 03.09 .2018

Kabul Tarihi: 16.05.2019 
Toplumsal cinsiyet, çok geniş bir yelpazede ele alınmaktadır. Sosyal psikoloji alanında toplumsal cinsiyet rolleri, kalıpyargılar, kadınlara ilişkin tutumlar, erkeklere ilişkin tutumlar, kendini kadınsı, erkeksi ya da androjen olarak algılama ve tanımlama, erkeklik, toplumsal cinsiyet rollerini ve bu rollerin altında yatan ideolojileri onaylama gibi birçok değişken incelenmiştir. Türkiye'deki cinsiyetçilik yazınına bakıldığında ise, kadınlara ilişkin tutumlar konusuna daha fazla ağırlık verildiği görülmektedir. Bu tür bir yaklaşım Türkiye'deki cinsiyetçilik düzeyi göz önüne alındığında (örn., Sakal11-Uğurlu, 2002, 2008) oldukça yerinde ve gerekli gözükmektedir. Var olan kadın odaklı toplumsal cinsiyetçilik çalışmalarına ilaveten, erkeklik, erkeksilik ve erkeklere ilişkin tutumlar gibi konuların eklenmesi toplumsal cinsiyetçiliğin temel motivasyonlarını açığa çıkararak, toplumsal cinsiyet eşitsizliğini hangi bağlamlarda etkilediğini göstermeye yardımcı olabilir; yurtiçinde erkeksilik/erkeklik konularına dikkat çekerek bu konuda çalışmak isteyenlere yol gösterici olabilir. Bu nedenlerle bu makalenin amacı, erkek olmak ile ilintili kalıpyargılar, erkeksilik ve erkekliği belirleyen unsurları ortaya çıkarmayı amaçlayan ölçek geliştirme çalışmaları, erkeklere ilişkin tutumlar, erkeklik ve erkek olmanın ya da ol(a) mamanın yarattığı stres gibi konuları ele alan çalışmaları sosyal psikolojik bir açıdan kalıpyargılar, önyargı ve ayrımcılık üçgeni içinde derlemektir.

Günlük dilde erkeksilik ve erkeklik kavramları birbiri ile örtüşen ve birbirinin yerine kullanılan kelimelerdir. Bilimsel çalışmalarda da bu iki kavramın benzer tanımlandığı ve birbirinin yerine kullanımı görüldügü gibi, farklı bilimsel alanlara, farklı konulara ve çalışılan spesifik temalara göre bazen erkeksilik bazen de erkeklik kavramının tercih edildiği görülmektedir. Daha sonra ele alınacağı gibi, genel olarak toplumsal cinsiyetçilik ideolojilerinin etkisi altında erkek olmaya atfedilen özelliklerin kişi tarafından sahiplenilmesi ve yansıtılması durumu erkeksilik (masculinity) (örn., Bem, 1974); toplumsal normlar çerçevesinde geleneksel erkeklik ideolojisinin beklentilerini davranışa dökme veya dökmeme arasında gidip gelen bir performanslar bütünü (örn., Connell, 1995) ve sosyal statü kazanım çabası (örn., Vandello ve Bosson, 2013) ile daha da ilintili bir kurgu durumu ise erkeklik (manhood) olarak tanımlanmıştır. Yazında bu tür kavramsal ayrımlar veya farklı kelime tercihleri söz konusu olduğu için atıf verilen yayınlarda hangi kavramı kullanıldı ise bu makalede o şekilde çevrilerek kullanılmıştır.

Bu makalede, erkek olmak ile ilintili kalıpyargilar, erkeksilik, erkekliği belirleyen unsurlar, erkeklere ilişkin tutumlar, erkeklik gerekliliklerini yerine getirme /getirememe sonucunda oluşabilen kayg1 ve stres gibi konular kalıpyargı, tutum ve ayrımcılık temelinde sosyal psikolojik bir yaklaşımla ele alınmıştır. Ele alınan çalışmalar genellikle ölçek geliştirme niteliğinde (bkz. Tablo 1) olsalar bile korelasyonel, yüz yüze görüşme ve deneysel gibi farklı yöntemler kullanılarak yapılan bu çalışmaların bilişsel, tutumsal ve davranışsal yönleriyle gözler önüne serilmesinin faydalı olacağı düşünülmüştür. Daha detaylı olarak ele alındığında görülebilebileceği gibi, toplumsal cinsiyet kalıpyargıları her iki cinsiyetin de ne yapması ya da yapmaması gerektiği konusundaki sosyal çağrılardır. Erkekler sosyalizasyon sürecinde bu kalıpyargıları öğrenirler ve farklı düzeylerde benimserler. Benimsenen bu kalıpyargilar bireyin var olan sosyal kuralları benimsemesi veya uymasına ilişkin tutumlarla olduğu kadar yaşadıkları stres ile de ilişkilidir. Hem kalıpyargılar hem tutumlar erkeklerin kendilerine veya diğerlerine yönelik olumsuz davranışlarıyla ilintilidir.

$\mathrm{Bu}$ çerçevede, makalede ilk olarak toplumsal cinsiyet kalıpyargıları hakkındaki bilgiler eşliğinde erkeklerin nasıl betimlendiği ve nasıl olmaları ya da olmamaları gerektiği konularıyla ilintili açıklamalara yer verilecektir. Daha sonra, bilişsel, duygusal ve davranışsal eğilimleri içeren erkeklik ve erkeklere ilişkin tutumların incelendiği çalışmalara değinilecektir. Bireylerin erkeklere, erkekliğe ve erkek cinsiyet rolü stresine ilişkin duygu, düşünce ve davranışsal eğilimlerini ölçmeye odaklanan çalışmalar ele alınacaktır. Sonrasında, kırılgan erkeklik konu alan deneysel çalışmalara yer verilecektir. Ayrıca, erkeklerin sahip oldukları erkeksilik ve erkeklik algılarıyla kendilerine veya diğer gruplara verdikleri zararlar ayrımcılık çerçevesinde kısaca özetlenecektir. Son olarak, ele alınan konularda Türkiye'de yapılan erkeksilik/ erkeklik çalışmaları, okuyucuya kolaylık sağlaması açısından, ayrı bir başlık altında sunulacaktır.

\section{Kalıpyargılar Bağlamında Erkeksilik/Erkeklik Çalışmaları}

Kalıpyargılar kişilerin herhangi bir grup hakkında zihinlerinde oluşturdukları sabit resimler olarak tanımlanmıştır. Toplumsal cinsiyet kalıpyargıları toplumun cinsiyetlere atfettiği özelliklerle ilgili yüklemelerdir. Kadınlara bazı özellikler atfedilirken, erkeklere diğer özellikler atfedilir (Spence ve Helmreich, 1978; Williams ve Benetts, 1975). Yurt dışındaki çalışmalarda erkekler atılgan, korkusuz, akılcı, güvenli, bağımsı, soğukkan11, güçlü, katı, saldırgan ve aktif olarak tanımlanırken; kadınlar sevecen, duygusal, hassas, bağımlı, şefkatli, boyun eğen, mütevazi, narin ve pasif olarak tanımlanmıştır (Ellis ve Bentler, 1973; Spence, Helmreich ve Stapp, 1974, 1975). Bu kalıpyargılardan da anlaşılacağ1 üzere, insanlar kadınları diğerlerini de kapsayan ortak amaçlar, erkekleri ise bireysel amaçlarla ilintili olarak algılamaktadirlar (Bem, 1974; Spence ve Helmrich, 1978). Ortak amaçlar çerçevesinde kadınlar kendi dışındaki kişilerle ilgilenme, diğerleri ile bağlantılı olma ve kendini diğerle- 
rine ifade edebilme ile ilişkilendirilirken; bireysel amaçlar çerçevesinde erkekler kendini kabul ettirme, kendini geliştirme, kendinden emin olma ve başarı odaklı olma gibi özelliklerle ilişkilendirilmektedir (Deaux ve Kite, 1993). Kalıpyargılardaki bu farklılaşma toplumda kadın ve erkek arasındaki statü farklarına; kadınların düşük pozisyonlarda çalışmasına ve erkeklere göre daha düşük bir statüde görülmesine bağlı olarak ortaya çıkmaktadır (Eagly ve Steffen, 1984; Eagly ve Wood, 1982).

Toplumsal cinsiyet kalıpyarg1ları, betimleyici (descriptive), buyurgan (prescriptive) ve yasaklayıcı (proscriptive) ögeleri yansitabilir. Betimleyici öge, kadın ve erkeklerin nasıl olduğu/tanımlandığı ile alakalı iken; buyurgan ve yasaklayıcı öge kadın ve erkeklerin nasıl olması/tanımlanması gerektiği ile ilgilidir (Burgess ve Borgida, 1999; Spence ve Helmreich, 1978; Terborg, 1977). Betimleyici kalıpyargılar, toplumsal cinsiyet bağlamında erkek ve kadınlar hakkındaki bilgilerin organize edilmesi işlevini görür. Bir kişinin toplumsal cinsiyetinden yola çıkarak kim olması veya olmaması gerektiğini içeren buyurgan ve yasaklayıcı ögeler ise kişiler arası ilişkilerdeki rollerle bağlantılıdır. İdeolojik motivasyona sahip olan buyurgan ve yasaklayıcı ögeler, var olan toplumsal cinsiyet yapısının desteklenmesi ve devam ettirilmesi işlevini görür (Burgess ve Borgida, 1999; Rudman, Moss-Racusin, Phelan ve Nauts, 2012). Buyurganlık ve yasaklayıc1lı ögesine sahip olan cinsiyet kalıpyarg1ları, toplumda ideal erkeklik algısının oluşmasında rol oynar. Erkekleri kariyer-odaklı, lider vasıflı, öfkeli, girişken, bağımsız, hırslı, çalışkan, baskı altında bile iyi çalışabilen, zeki, analitik, ikna edici, yeterli ve rekabetçi olarak idealize ederken; kadınları duygusal, sevecen, çocuklarla ilgilenen, başkalarını düşünen, iyi bir dinleyici, arkadaş canlısı, kibar ve yardımsever olmak gibi özelliklerle idealize eder. Bu kalıpyargılar bir yandan erkeklere atfedilen "avantajl1-güçlü” toplumsal statüyü onamaktayken, diğer yandan da statüyü tehlikeye atan "kadınsı" kalıpyargıları taşımanın olumsuz sonuçlarını da beraberinde getirmektedir (Rudman ve ark., 2012). Örneğin, kendini daha bireysel amaçlarla tanımlayan erkekler toplumsal cinsiyet temelli eşitsizliği daha fazla meşrulaştırmakta ve daha geleneksel ebeveynlik rollerini daha fazla desteklemektedirler (Kosakowska-Berezecka, Besta, Adamska, Jaśkiewicz ve Vandello, 2016).

Buyurgan ve yasaklayıcı kalıpyargılar toplumsal cinsiyet yapısını meşrulaştırırken önyargılı tutumların ve niyetli bir ayrımcılığın ortaya çıkmasına da yol açar (Burgess ve Borgida, 1999; Rudman ve Phelan, 2008). Örneğin, insanlar buyurgan kalıpyargılarla uyuşmayan patronların altında çalışanları "kalıpyargı dışında" alg1lamakta ve ayrımcılık yapmaktadır. Altında çalıştıkları kişiler kalıpyargılara uymayan bir pozisyondaysa (inşaat işinde patronun kadın olması gibi), bu kişilerin altında ça- lışan erkekler daha az kazanca layık görülmekte ve güç, bağımsızlık gibi erkeklere atfedilen kalıpyargılara uygun görülmemektedir (Brescoll, Uhlmann, Moss-Racusin ve Sarnell, 2012). Bununla birlikte, erkeklere ilişkin kalıpyargılara uymadığı söylenen erkekler, erkekliklerine yönelik tehdit algilamakta ve kendilerini ispatlamak adına cinsiyetçi ve homofobik esprilere sarılmaktadır (O'Connor, Ford ve Banos, 2017). Aynı zamanda erkekler, kadınlara kıyasla buyurgan kalıpyargılara uymanın daha önemli olduğunu belirtirken (Burgess ve Borgida, 1999; Deaux ve Kite, 1993), geleneksel cinsiyet rollerini de daha fazla benimsedikleri görülmektedir (Twenge, 1997). Bu şekilde ataerkil toplumdaki avantajlı konumlarını korumakta (Pratto, Stallworth ve Sidanius, 1997) ve toplumsal iktidarın devamını sağlamaktadır (Laws, 1979).

Toplumsal cinsiyet kalıpyargılarını kapsayan en popüler çalışma Bem'in (1974) androjenlik kavramını da vurguladığ1; toplumsal cinsiyet rollerinin birbirinin Zıttı olmadığını, hatta bağlama bağlı olarak kişilerin hem erkeksi hem de kadınsı özellikleri taşıyabileceğini öne sürdüğü araştırmasıdır. Bu araștırmasında Bem (1974) ilk olarak araştırma grubuyla birlikte kadınsı ve erkeksi özellikleri yansıtan 400 sıfat yazmıştır. Daha sonra katılımcılardan, belirlenen bu sıfatların Amerikan kültüründe ne kadar istenir olduklarını belirtmeleri istenmiştir. $\mathrm{Bu}$ aşamada yapılan işlem kalıpyargılar çalışmalarına paralel olarak kadınsı ve erkeksi özellikleri tanımlayan kalıpyargıları belirleme aşaması niteliğindedir. Bem'in bu ölçeği, erkeklere atfedilen bireysel ve kadına atfedilen ilişskisel amaçlarla ilintili kalıpyargıları ölçmektedir (Abele ve Wajcisizke, 2007; Fiske, Cuddy, Glick ve Xu, 2002). Bem (1974) çalışmasının son aşamasında, Amerikan toplumundaki kalıpyargıları yansıtan kadınsı ve erkeksi özellikleri içeren bu sıfatlardan 60 tanesini seçerek Bem'in Cinsiyet Rolü Envanterini oluşturmuştur ve katılımcıların erkeksi (lider, hırsl1, baskın), kadınsı (şefkatli, güler yüzlü, hassas) ve nötr (uyumlu, mutlu, güvenilir) özellikler üzerinden kendilerini nasıl tanımladıklarını ölçmüştür. Bu açıdan da bu ölçek kadınsı, erkeksi ve androjen kişilik özelliklerini ölçen ölçekler grubuna dahil edilmektedir. $\mathrm{Bu}$ ölçeğe göre bir kişi erkeksilik boyutundan yüksek, kadınsılık boyutundan düşük bir puan alırsa erkeksi; kadınsılık boyuttan yüksek, erkeksilik boyutundan düşük puan alırsa kadınsi; her iki boyuttan da yüksek puan alırsa androjen; her iki boyuttan da düşük puan alırsa farklılaşmamış özellikler yansıtmaktadır. Bem'in bu çalışmasından yola çıkarak Kachel, Steffens ve Niedlich (2016) Geleneksel Erkeksilik-Kadınsılık Ölçeği'ni geliştirmiştir. Bu yeni ölçek kişinin, kendisini ne kadar erkeksi/kadınsı algıladığ1; ne kadar erkeksi/kadınsı olmak istediği; ve ilgi, tutum, davranış ve fiziksel görünüm açısından kendisini tipik cinsiyet kuralları ile ne kadar özdeşleştirdiği ile ilgili- 
dir. Böylece kişinin cinsiyet rolleriyle ilintili benlik algisının ölçüldüğü ileri sürülmüştür.

Bem'in erkeksilik/kadınsılık çalışmasına benzer şekilde yaklaşan Spence, Helmrich ve Stapp (1974) Kişisel Özellikler Ölçeği'ni geliştirmiş̧ir. Bu ölçek, toplumda kadın ve erkekler için yüksek istenirlikte olan kişilik özelliklerini kapsamaktadır. Katılımcılar, verilen kişilik özelliklerinin kendileri için ne kadar geçerli olduğunu belirtmişlerdir (Spence ve Helmrich, 1978). Spence, Helmreich ve Holahan (1979) ise kişisel özellikler ölçeğindeki sıfatların olumlu ve olumsuz erkeksi özellikleri yansıttığını göstermişlerdir. Örneğin, sorumlu ve başarılı olumlu; buna karşın, saldırgan ve sömüren olum$s u z$ erkeksi özellikler olarak ele alınmıştır. Bem'in Cinsiyet Rolleri Envanteri ve Spence, Helmrich ve Stapp'in Kişisel Özellikler Ölçeği yazında cinsiyet rol oryantasyonunu ölçmek için kullanılmaktadır (Lenney, 1991). $\mathrm{Bu}$ ölçekler kişilerin kendi erkeksilik düzeylerini (örn., "Ben girişkenim") ölçebilecekleri araçlardır.

Yukarıdaki ölçeklerle ölçülen geleneksel kalıpyargısal özellikler toplumsal rizayı temsil ettiğinden, bu r1zanın dışına çıkanlara ayrımcılık yapılmasını ve cezalandırmayı da meşrulaş̧ırmaktadır (Rudman ve Fairchild, 2004). Cinsiyet kalıpyargılarının dışına çıkan veya bu kalıpyargılara aykırı algılananlar hem toplumsal hem de somut cezalandırmalara maruz kalmaktadırlar (Rudman ve Phelan, 2008). Kalıpyargılara uymamak, özellikle buyurgan ve yasaklayıcı kalıpyargıları karşılayamamak erkeklere yönelik olumsuz tutumlar ve yaptırımlarla sonuçlanabilir. Bir erkeğin kadınsı işler yapması, aşırı nazik ve kibar görülmesi başkalarının gözünde onun yetkinliğini düşürmekte ve eşcinselliği ima etmektedir (Rudman ve Phelan, 2008). Benzer bir etki, alçakgönüllü görülen erkeklere yönelik de görülmektedir. Alçakgönüllülük daha çok kadınları tanımlayan bir kalıpyargı olarak görülmekte, bu sebeple erkeklerin alçakgönüllü olması özellikle de bir iş pozisyonu için değerlendirilirken statü uyumsuzluğu yaratmaktadır. Zayıflık ve kendinden emin olmama gibi yasaklayıc1; hırslı ve kendinden emin olma gibi buyurgan kalıpyargılara ters düştüğünden, alçakgönüllü erkekler pek sevilmemekte ve statü gerektiren iş pozisyonları için uygun görülmemektedir (Moss-Racusin, Phelan ve Rudman, 2010; Rudman, Mescher ve Moss-Racusin, 2012). Toplumsal cinsiyet normlarının zamanla değişmesi, özellikle erkeklerin daha eşitlikçi bir görüşü paylaşmalarılla mümkün görünse de; yapılan bu çalışmalarda eşitlikçi erkekler olumsuz değerlendirilmektedir.

\section{Tutumlar Bağlamında Erkeksilik/Erkeklik Çalışmaları}

Tutum bir nesneye ilişkin olumlu ya da olumsuz duygu, düşünce ve davranış eğilimlerinin öğrenme sonucunda zihinde tortulaşmış hali (Sakallı-Uğurlu, 2018) olarak ele alınırsa, erkeklik olgusuna ilişkin tutumları bu düzeyde incelemek ve ölçekler geliştirmek mümkündür. Alandaki kalıpyargı çalışmaları daha çok erkeksilik ve erkeğe atfedilen cinsiyet rolleri üzerine odaklanırken; paralelinde, tutum çalışmaları erkekliğin altında yatan temaları belirleme ve erkeklerin toplumdaki cinsiyet kurallarını benimsemesi ve uyması gibi konular üzerine yoğunlaşmaktadır. Bu farklı yaklaşımlara göre, erkeksilik, toplumdaki erkeğe dair, erkeği niteleyen özelliklerin kişi tarafindan sahiplenilmesi ve yansıtılmasıdır. Kişinin dış görünüşü, davranışları, sesi veya icra ettiğgi toplumsal rolleri "erkeksi" olarak nitelenebilir. Erkeklik ise daha çok toplumsal bir duruma ve eylemliliğe işaret eder ve geleneksel erkeklik ideolojisinin beklentilerini eyleme dökme veya dökmeme arasında gidip gelen bir performanslar bütünü olarak tanımlanmaktadır (Connell, 1995). Erkeklik, kültürel düzeyde oluşan sosyal kurallar çerçevesinde, erkeklerin ne yapıp-yapmaması gerektiğini belirten öğretiler ve kişilerin bu sosyal kuralları ne kadar benimseyip-benimsemediği şekliyle tutumlar düzeyinde de ele alınmıştır.

Üstte belirtilen erkeksilik ve erkeklik kavramlarının farklı tanımlanmasina paralel olarak, yazında erkeksilik ve erkeklik kavramları kişilik özellikleri veya normatif yaklaşım (sosyal kurallar) olarak iki farklı yaklaşımla incelenmiştir. Kişilik özellikleri yaklaşımı (trait approach) toplumsal olarak erkeksi özelliklere ve davranışlara sahip olma gibi erkeksilikle ilintili konuları inceler. Diğer bir deyişle, kişinin kendini nasıl tanımladığıyla alakalıdır. Bu yaklaşıma göre bir erkek, erkeksi özelliklere ne kadar sahipse kadınlardan o kadar fazla ayrışır. Bu yaklaşıma uyan Bem Cinsiyet Rolleri Envanteri (Bem, 1974) ve Spence Kişisel Özellikler Ölçeği (Spence ve Helmreich, 1978) katıllmcilardan kendilerini belirli kadınsı ve erkeksi özelliklere göre tanımlamasını istemektedir. Kişilik özellikleri daha çok betimsel kalıpyargilarla paralel ilerlemektedir.

Normatif yaklaşım (normative approach) ise buyurgan ve yasaklayıcı kalıpyargılarla paralel ilerleyebilecek özelliktedir. Bu yaklaşıma göre erkeklik, psikolojik, biyolojik veya fiziksel özelliklere sahip olmayı değil; cinsiyet ilişkileri ve tutumlarını belirleyen kültürel bir ideolojiyi yansitır (Thompson ve Pleck, 1995). Bu yaklaşıma göre erkeklik ideolojisi birey olarak erkekleri kültürel erkeklik ideali ile ilişkilendirir; erkeklerin kendilerini toplumsal rollere göre tanımlamalarından ziyade, toplumdaki ideal erkeğin nasıl olması, davranması veya düşünmesi gerektiğini dikte eden kuralları ne kadar benimsediğini/uyguladığını gösterir (Pleck, Sonenstein ve Ku, 1993; Thompson, Pleck ve Ferrera, 1992). Erkeklik ideolojisi, erkek baskınlığının kadınlar ve diğer erkek grupları üzerinde devamlılığına izin veren beklentiler, kimlikler ve davranış kalıpları (Connell ve Messersch- 
midt, 2005) olarak tanımlanan hegemonik erkeklik ile benzer anlamları taşımaktadır. Bu açıdan içselleştirilen erkeklik ideolojisi, erkekliğin farklı erkek grupları arasında veya diğer cinsiyet gruplarına yönelik nasıl icra edildiğini belirleyen bir etkendir. Örneklendirmek gerekirse, kişilik yaklaşımına göre geleneksel bir erkek, toplum tarafından tanımlanmış erkeksi kalıpyargısal özellikleri taşıyan kişidir. Normatif yaklaşıma göre geleneksel erkek, bir erkeğin kesinlikle erkeksi özellikleri taşıması gerektiğini söyleyen ideolojiyi içselleştiren ve toplumsal olarak uygulayan kişidir (Thompson ve ark., 1992).

1970'lerden beri birçok araştırmacı kullandıklar1 farklı tutum ölçekleriyle erkeksi olanı ve erkekliği tanımlamak için temel temaları belirleme çabasındadır (Smiler, 2004). Bu amaçla geliştirilen ölçeklerden bazıları kişilik özellikleri yaklaşımını, bazıları ise normatif yaklaşımı benimsemişlerdir. Cinsiyet rollerine ilişkin kalıpyargılar, sosyal kurallar, erkeksilik (ve kadınsılık), erkeklik, erkeklik ideolojisi, cinsiyet rollerinde çatışma, cinsiyet rollerinde eşitlik ve erkekliği tanımlayan sosyal kuralların ve değerlerin değişmesi gibi tutumları ele alan bu ölçeklerin bir kısmı Tablo 1'de sunulmaktadır. Tablo 1 'de görülebileceği gibi bu ölçeklerde erkekliği yansıtan bileşenler, statü ve/veya başarı (başarı, kariyer, kaynak yönetimi vb.), sertlik (rahatsızlığa tolerans, benlik kısıtlaması, duygusal bağlantısılık, fiziksel güç vb.), kadınsılıktan kaçınma (kadınsı davranışlardan uzak durma, kadını küçümseme, kadını cinsel obje olarak görme vb.), ataerkil öğretilerin kabulü, eşcinsellikten korkma/nefret, kendine güven, saldırganlık, cinselliğe ilişkin tutumlar ve duygusallığın kısıtlanmasıdır. Bu bileşenler çalışmaların amaçlarına ve araştırmacıların elde ettikleri faktör yapılarına göre değişse de birçok yönden birbirileri ile kesişmektedir.

Normatif yaklaşımı takip eden bazı araştırmacılar sosyal-kültürel olarak belirlenen rollerin bireyler tarafından içselleştirildiğini ve erkekliğin toplumda kadınlığın tam tersi olarak görüldüğünü ifade etmektedir (Brannon, 1976; Mahalik ve ark., 2003; Luyt, 2018). Alanda bu konuyu ilk çalışan araştırmacılar erkek olabilmek için kadınsı olmama ve kadınsılıktan kaçınmanın yanı sıra başarıyı arama ve duyguları bastırma gibi temaların olduğunu belirtmişlerdir (Pleck ve Sawyer, 1974). Brannon ve Juni (1984) erkek olmak için yapılması ve yapılmaması gereken davranışları içerecek dört temadan bahsetmişlerdir. "Erkek olmak" için yapılmaması gerekenler arasında (1) kadınsı olmama ve kadınsı davranışlardan kaçınma yer almaktadır. Buna karşın, "erkek olmak” için yapılması gerekenleri belirten sosyal kurallar içinde (2) statü kazanma çabası (3) bağımsızlık ve kendine güven, (4) saldırgan davranışlar gösterme yer almaktadır. Brannon'un ölçeğini sadeleştiren Thompson ve Pleck (1986) ise geleneksel erkekliği statü, sertlik ve kadınsılıktan kaçınma boyutları ile ele almıştır (Erkek Rol Normları Ölçeği, bkz. Tablo 1). Yazında çok kullanılan bu ölçek erkeklik ideolojisini ölçer. Bu ölçekte statü, erkeklerin sosyal statüye ve diğerlerinin saygısına sahip olmasi; sertlik erkeklerin fiziksel olarak güçlü ve saldırganlığa hazır olması; kadınsılıktan kaçınma ise erkeklerin kadıns1 olmamas1 ve kadıns1 aktivitelere katılmaması olarak ele alınmıştır.

Benzer şekilde, Levant ve arkadaşları (1992) Erkek Rol Normları Enventari'ni (ERNE) geliştirerek geleneksel ve geleneksel olmayan erkek rol normlarını ölçmeyi amaçlamışlardır. Bu bağlamda erkeklik ideolojilerinin erkeklerin davranışlarını belirleyen kültürel normlar veya standartlar olduğunu belirtmişlerdir. Bu ideolojiler erkeklerin sosyalleșme ve olgunlaşma sürecini etkiler ve erkeklik normlarına uymaları için baskı yaratır (Levant, 2011). Alanda sık kullanılan ölçeklerden bu bağlamda farklılaştıklarını iddia eden Levant ve arkadaşları (1992), Thompson ve Pleck'in (1986) ölçeğinin erkekliğin birçok bileşenini yansıtmadığını düşünerek; erkeklik ideolojisini daha geniş kapsamlı ve çok kategorili olarak ele almayı hedeflemişlerdir (Thompson ve Bennett, 2015). ERNE 2000'li yıllarda birkaç kere revize edilmiş (Levant ve ark., 2007; Levant, Ronkin, Williams, Hasan ve Smolley, 2010) ve 2010 yılındaki çalışmada 7 faktörlü ve 39 ifadeli olarak kullanılmıştır. Tablo 1'de verilmeyen bu revizyonda, kadınsılıktan kaçınma, cinsel azınlıklara ilişkin olumsuz tutum, mekanik beceriler düzeyinde kendine güven, sertlik, baskınlık, cinselliğin önemi ve duygusallığın kısıtlanması faktörleri vardır (Gerdes, Alto, Jadaszewski, D'Auria ve Levant 2017). Aynı ölçek daha sonra çoklu faktör yapısında bir değişiklik yapılmadan 21 ifadeye indirilmiş (Levant, Hall ve Ronkin, 2013) ve son faktör yapısı da yapısal eşitlik modeli ile teyit edilmiştir (Levant, Hall, Weigold ve McCurdy, 2016).

Mahalik ve arkadaşları (2003) ise cinsiyet rollerine ilişkin sosyal kuralları erkeksi ve kadınsı davranışları yönlendiren ve sınırlarını belirleyen sosyal kurallar olarak ele almaktadir. Erkek rollerine uyma kavramı erkeklerin toplum tarafindan belirtilen bu beklentilere uyup-uymama durumunu yansıtır. Mahalik ve arkadaşları (2003) daha önce geliştirilen ölçeklerin sınırlı sayıda alt faktör içerdiklerini ve erkeklik ideolojisine dair ayrıntılı ve çok boyutlu bir yaklaşım izlenerek anlamaya çalıştıklarını belirtmişlerdir. Geliştirdikleri Erkeksi Normlara Uyum Envanteri her ne kadar Brannon ve Juni'nin (1984) Brannon Erkeklik Ölçeği'ne, Thompson ve Pleck'in (1986) Erkek Rol Normları Ölçeği ve Levant ve arkadaşlarının (1992) Erkek Rol Normları Envanteri'ne benzese de; ölçüm maddeleri bireyin söz konusu ideolojiye ne kadar uyduğunu ölçmektedir (örn., "Kazanmak benim için çok önemlidir.”). 


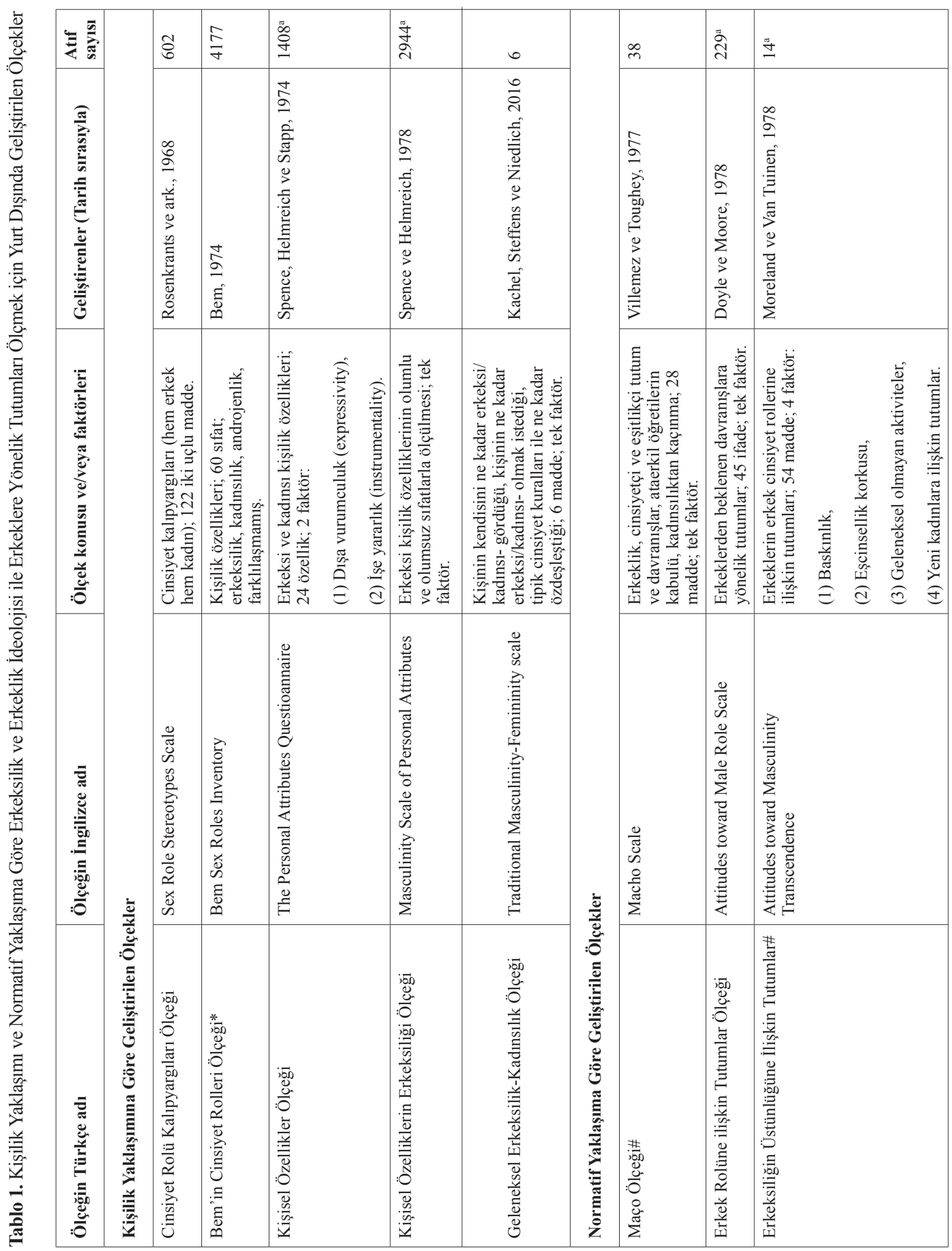




\begin{tabular}{|c|c|c|c|c|}
\hline in & $\stackrel{0}{-}$ & $\frac{\infty}{m}$ & I & $\underset{\sim}{\sim}$ \\
\hline 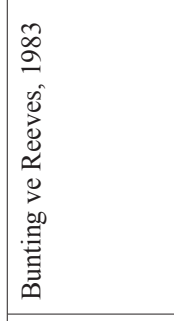 & 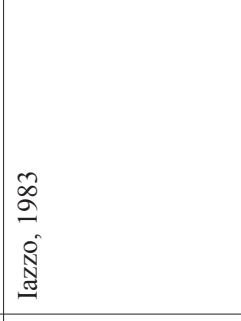 & 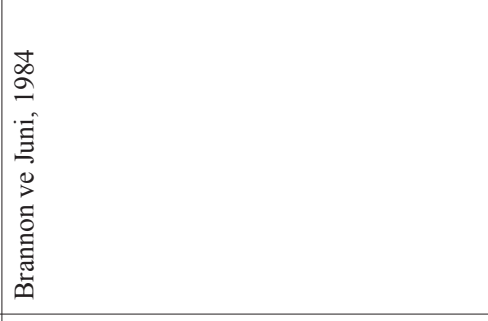 & 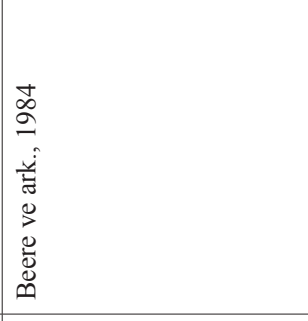 & 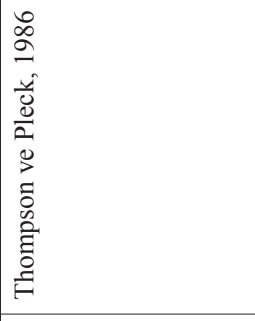 \\
\hline 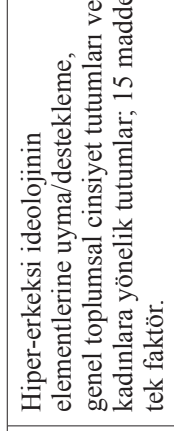 & 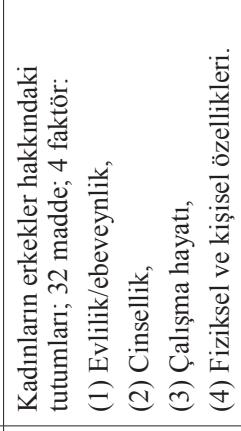 & 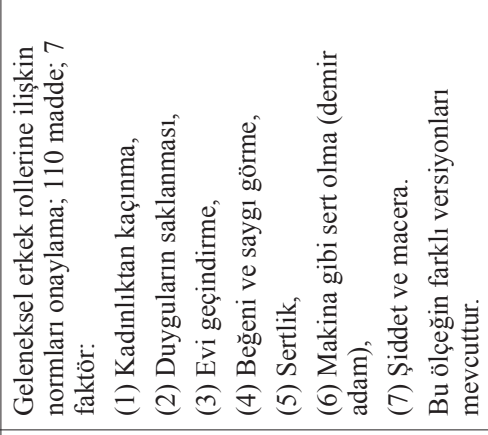 & 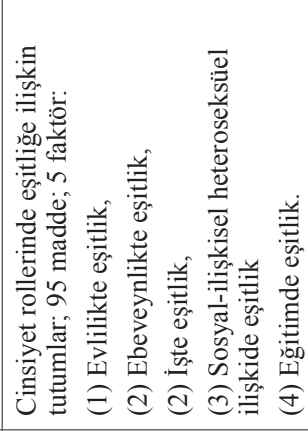 & 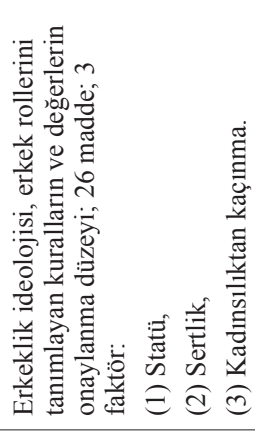 \\
\hline 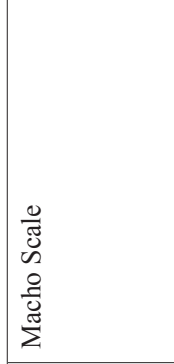 & 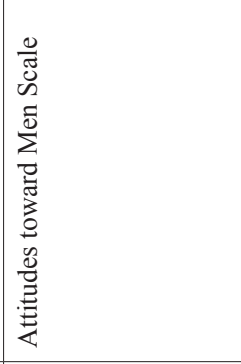 & 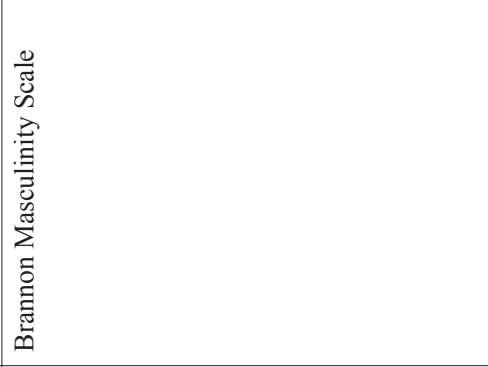 & 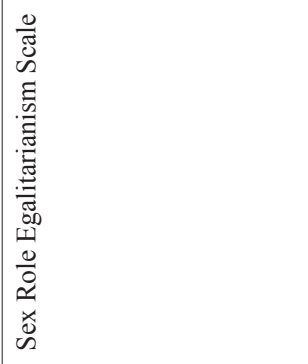 & 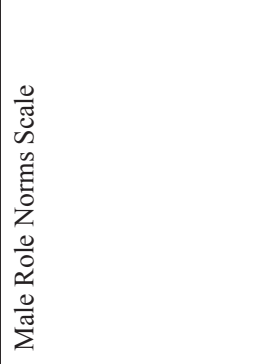 \\
\hline 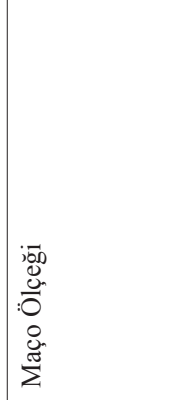 & 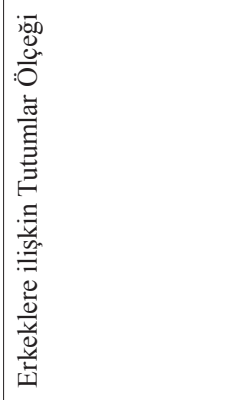 & 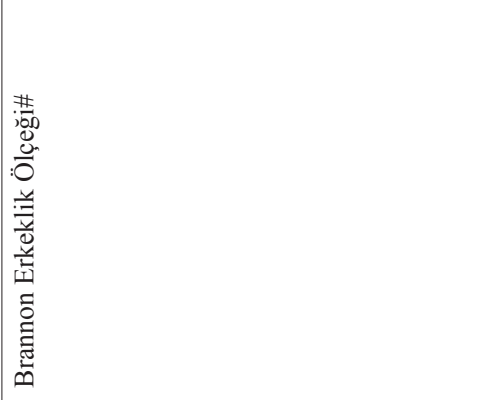 & 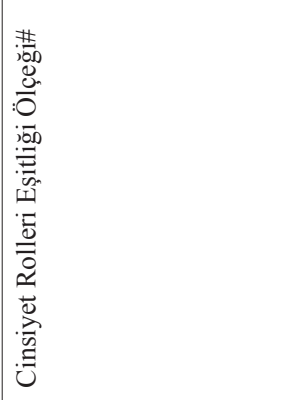 & 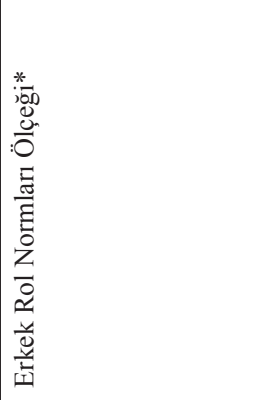 \\
\hline
\end{tabular}




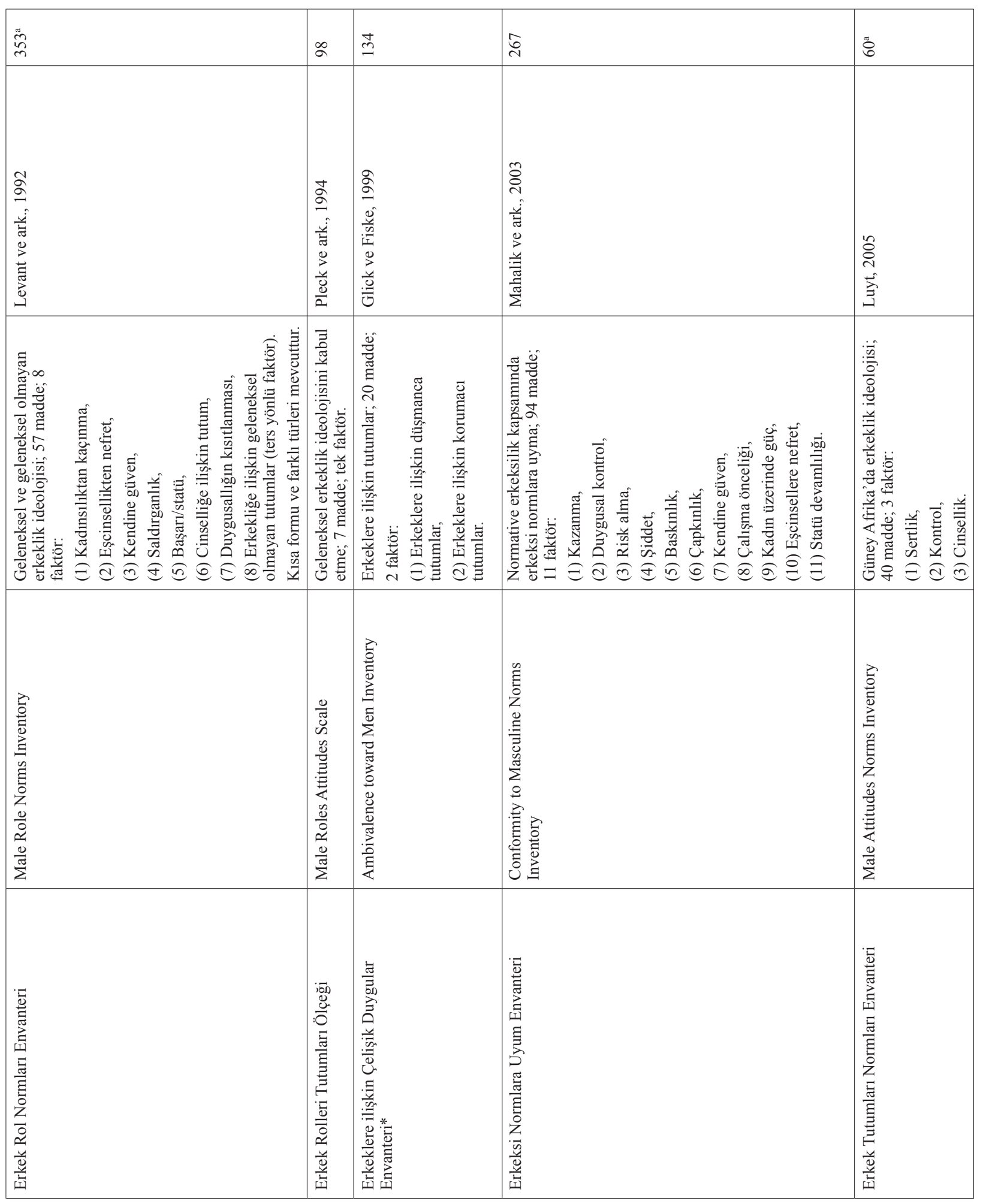




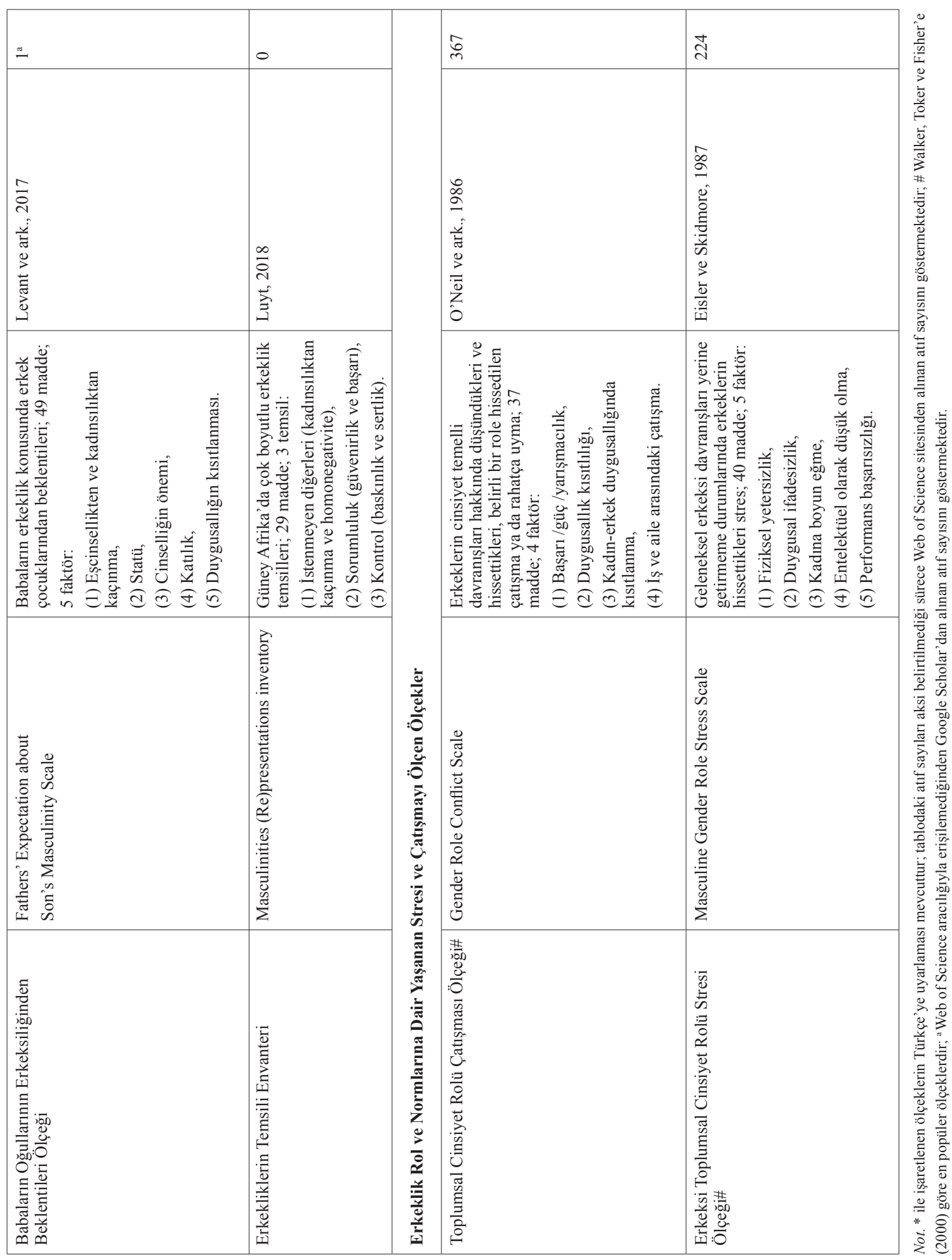


Son olarak, erkeklerin kadın üzerinde sahip olduğu gücü, baskınlığı ve zayıf gördüğü kadını korumasını içeren erkeklik ideolojisi ile kadınların bu yapıya gücenmesi arasındaki çelişkiye ağırlık veren Erkeklere ilişkin Çelişik Tutumlar Ölçeği (Glick ve Fiske, 1999) ele alınabilir. Bu ölçek, erkeğe ilişkin düşmanca ve korumacı tutumları kapsamaktadır. Erkeğe ilişkin düşmanca tutumlar faktörü altında ataerkilliğe içerleme, cinsiyetler aras1 ödünleyici farklılaştırma ve heteroseksüel düşmanlık bulunmaktadır. Olumsuz tonda olan bu alt faktör erkeklerin her zaman güç ile ilintili avantajlara sahip olacakları algısını içermektedir. Erkeğin kadınlarla ilişkilendirilen rollerde (özellikle ev işleri rollerinde) yeteneğinin olmadığını, kadınların erkeğin gücüne ve bu gücün kötüye kullanılmasına içerlemelerini vurgulamaktadır. Bu özellikleri ile bu boyut erkeğin olumsuz yönleriyle "nasıl" olduğunu betimlemektedir. Erkeğe ilişkin korumac1 tutumlar alt faktörü ise geleneksel toplumsal cinsiyet rollerine ve güç ilişkilerine olumlu açıdan yaklaşmakta, toplumda var olan sosyal sistemi haklı çıkarma çabasını göstermekte ve daha çok erkeğin ideal olarak "nasıl olması gerektiği" konusuna eğilmektedir. Bu faktör, anaerkillik, cinsiyetler arası tamamlayıcı farklılaştırma ve heteroseksüel yakınlık boyutlarını içermektedir (Glick ve Fiske, 1999; Glick ve ark., 2004). Hem yoğun bir ataerkillik hem de anaerkillik içeren bu ölçek Türkiye'de de geçerli ve güvenilir bulunmuştur (detaylı bilgi ve ölçek ifadeleri için bkz. Sakallı-Uğurlu, 2008).

Şimdiye kadar genel olarak geleneksel erkeklik ideolojisini ölçmeyi hedefleyen ve bunu farklı bakış açılarıyla ayrıntılandıran en popüler ölçekler metin içinde sunulmuştur. Diğer ölçekler, ifade sayıları ve alt faktörleri ise Tablo 1'de verilmiştir. Ayrıca, Tablo 1'da görüldüğü gibi, bazı araştırmacılar erkeklik ideolojisinin buyurgan ve yasaklayıcı normlarıyla erkekler üzerinde stres ve kaygı yarattığına ve beklenen rollere uy(a)mama durumlarında olumsuz davranışlara yol açabileceğine ilişkin konulara da odaklanmışlardır. Makalenin bir sonraki alt başlığında toplumsal cinsiyet rollerinin yarattığ stres ve gerginliği ele alan bu çalışmalar sunulacaktır.

\section{Erkeklik Rollerini Yerine Getirememe}

\section{Gerginliğine/Stresine Odaklanan Çalışmalar}

Pleck (1981), sunduğu Cinsiyet Rol Gerginliği Modeli'yle toplumsal cinsiyeti sosyal inşacı bir perspektiften ele alarak, cinsiyet rolleriyle ilişkili sosyal kurallara uyma ya da uymama durumunda erkeklerde rahatsızlık yaratabilecek olası durumları vurgulamıştır. $\mathrm{Bu}$ durumlar, erkeklik ideolojisinin erkeklerin sosyalleşmesi sırasında yarattığı olumsuzluklardan kaynaklanmaktadır (Pleck, 1995). Pleck (1981) cinsiyet rollerinin hem kadınlar hem de erkekler için gerginlik yaratabileceğini ancak bu gerginliğin erkekler tarafından daha çok yaşandığını belirtmiştir. Garnets ve Pleck (1979)'e göre cinsiyet rol gerginliği, kişinin "gerçek cinsiyet benliği" ile kültürel-sosyal kurallara göre "olması gereken cinsiyet benliği” arasındaki farklılık sonucu oluşmaktadır. Diğer bir deyişle, özellikle toplumsal cinsiyet normlarına önem veren erkekler, toplumdaki cinsiyet rol standartları ile kendi performansları uyuşmadığında cinsiyet rol gerginliği hissetmektedirler. Benlikle ilgili olan bu durum, benlik saygısını da etkilediği için önemlidir. Katı cinsiyet rollerini içeren sosyal kurallar, kişiye kendini özgürce ifade etme firsatı sunmayabilir ve benlik saygılarına tehdit oluşturabilir. Kişiler değersizlik, eksiklik, rahatsızlık, gerginlik ve stres hissedebilirler (Levant, 1996; Pleck, 1981).

Pleck'in modeli büyük ölçüde, bir önceki bölümde ele alınan, Brannon'ın (1976) dört temasına (kadınsı davranışlardan kaçınma, statü kazanma çabası, bağımsızlık ve kendine güven, saldırgan davranışlar gösterme) dayanmaktadır. Pleck'e (1995) göre erkeklik ideolojisi, erkek cinsiyet rol stresinin merkezinde yer alır. Her birey erkeklik ideolojisini farklı düzeyde benimsediği için yaşanacak cinsiyet rol stresi de farklı düzeyde olabilir. Örneğin, orduda görevli bir erkek komutanın erkeklik ideolojisi ve yaşayacağı stress, üniversite'de çalışan akademisyen bir erkeğin erkeklik ideolojisinden ve yaşayacağı stresten farklı olabilir. Ayrıca, erkeklik ideolojisi ve yaşanan stres yaş, aile geliri, etnik grup gibi sosyo-ekonomik özellikler ile ilişkilidir (Pleck, Sonenstein ve Ku, 1993).

Benzer şekilde, alanda en çok kullanılan Erkeksi Cinsiyet Rolü Stresi Ölçeği (Eisler ve Skidmore, 1987) cinsiyet ile ilgili standartlara uyma çabası sırasında kişinin yaşadığı psikolojik (örn., güvensizlik, düşük benlik saygıs1, artan öfke) ve olumsuz fizyolojik (örn., kardiovasküler aktivitelerde artış) deneyimleri ele almaktadır. Bu stress bazen erkeklikle ilgili sosyal beklentilerin karşılanamaması durumunda, bazen de ortamın erkeği kadınsı davranmaya itmesi durumunda yaşanabilir. Eisler ve Skidmore (1987) erkeklerin fiziksel yetersizlik (erkeksi fiziksel özelliklere sahip olamama durumunda hissedilen stres; örn., fiziksel olarak iyi koşullarda olamama, kadınsı özelliklere sahip olma); duygusal ifadesizlik (duygularını ifade edememe; örn., korktuğunu kabul etme, çocuklarının kendisini ağlarken görmesi); kadına boyun eğme (iş ve spor alanında kadınların daha üstün olması durumunda hissedilen stres; örn., kadın bir müdürünün olması, kendinden daha çok kazanan biriyle evli olma); entellektüel anlamda hissedilen aşağılık hissi (mantıklı düşünememe ve bazı durumlarla zekice baş edememe durumunda yaşanan stres; örn., kaybolduğunda yön sormak zorunda kalma, kararsız olduğunun söylenmesi); performans başarısızlığı (iş ve cinsel açıdan başarısız olma durumunda hissedilen stress; örn., işsiz 
olma, yeterli para kazanamama) gibi konularda stress yaşabileceklerini belirtmişlerdir. Bu gibi durumlardan rahatsızlık duyanlar, toplumca atfedilen erkeklik statüsünü yeniden kazanmak adına daha erkeksi tavır ve davranışlarla geleneksel cinsiyet rollerini yerine getirmeye çalışırlar. Daha sonraki yıllarda, Swartout ve arkadaşları (2015) beş faktörlü ve 40 ifadeli Erkeksi Cinsiyet Rolü Stresi Ölçeği'ni kısaltarak her faktörden ifade bulunacak şekilde 15 ifadeye indirmiştir.

Benzer konulara odaklanan O'Neil ve arkadaşları (O’Neil, 2008; O’Neil, Helms, Gable, David ve Wrigtsman, 1986) cinsiyet rol gerginliği ve çatışmasını, cinsiyet rollerinin kişiyi veya diğerlerini olumsuz olarak etkilediği zaman oluşan psikolojik durum olarak tanımlamışlar ve Toplumsal Cinsiyet Rolü Çatışması Ölçeği'ni geliştirmişlerdir. Yazarlara göre cinsiyet rollerinin çiğnenmesi olumsuz psikolojik sonuçlara ve çatışmaya yol açar. $\mathrm{Bu}$ çatışmanın en önemli olumsuz çıktısı bireyin insan olarak potansiyellerini gerçekleştirme yeteneğini ya da çabasını azaltmasıdır. Araştırmacılar erkeklerin hem kendilerini belirli cinsiyet rollerinde nasıl gördüklerini hem de cinsiyet rol çatışması durumunda nasıl hareket ettiklerini ölçmeyi planlamışlardır. Bu amaçla da cinsiyet rol çatışması ölçeğinin iki versiyonunu geliştirmişlerdir (O’Neil ve ark., 1986). İlk versiyon kişisel tutumları (örnek ifadeler; "Duygularımı ifade etmekte zorlanırım" "Diğerlerinden daha başarılı olmaya çabalarım"); ikinci versiyon ise durumlara verilen tepkileri ölçmektedir (örnek durum sorusu; "En iyi arkadaşınız sizinde çalıştığınız fabrikadaki işini kaybetti. Bu nedenle tabii ki rahatsız, korkuyor ve kızgın. Ancak bu duygularını saklıyor. Arkadaşınızın bu yoğun duygularına ve korkularına tepki vermekte ne kadar rahatsınız?"). Kişisel tutumları içeren ilk versiyonda dört faktör (başarı/güç/yarışmacılık; kısıtlanmış duygusallık; erkekler arasında duygusallığın kısıtlanması; aile/iş ilişkilerinde çatışmalar) bulmuşlardır. Verilen durumlarda nasıl davranacaklarını ölçen ikinci versiyonda ise (1) başarı/güç/ yarışmacılık, (2) eşcinsellik korkusu, (3) duygusal tepkilerde eksiklikler ve (4) cinsiyet rollerinden sapma durumunda mahçup olma faktörlerini bulmuşlardır.

Erkeksi Toplumsal Cinsiyet Rolü Stresi (Eisler ve Skidmore, 1987) ve Toplumsal Cinsiyet Rolü Çatışması Ölçekleri (O’Neil ve ark., 1986), erkeklik ideolojisinden beslenseler de bu ideolojiyi ölçen normatif ölçeklerle aynı sınıfta değerlendirilmezler. Bu ölçeklerde bireysel olarak erkeğin geleneksel erkeklik normlarından dolayı yaşadığı stres ve gerginliğin ölçülmesi söz konusudur. $\mathrm{Bu}$ bağlamda erkeklik ideolojisini benimseyen erkeklerin, bu gerekleri karşıla(ya)madığında ya da rollerine dair statüleri sorgulandığında daha fazla stres ve gerginlik yaşaması beklenir. Bu iki ölçek birbirine benzer olsalar da kavramsal çerçeveleri ve ele aldıkları araştırma so- ruları bakımından farklı olduklarını iddia etmektedirler (Eisler, 1995). Her iki ölçek de baskın kalıpyargılardan esinlenerek üretilmiş faktörleri içermektedir. Cinsiyet rol stresi ya da çatışması çalışmaları normatif (sosyal kurallar) yaklaşımıyla ilintilidir. Her ikisi de erkeksi cinsiyet rol beklentilerine meydan okuma ya da benimseme durumunu içerebilmektedir.

Makalenin bu kısmına kadar erkeklik, toplumsal cinsiyet rolü çatışması ve stresi kavramlarını Likert tipi ölçeklerle ele alan çalışmalara yer verilmiştir. Ancak son yıllarda bazı sosyal psikologlar (örn., Vandello ve Bosson, 2013) erkekliğin sosyal yapısını neden-sonuç ilişkisi temelinde anlamak için kırılgan erkeklik kuramını ortaya atmışlardır. Daha önceki erkeklik çalışmalarını temel alarak erkekliğin zor kazanılan, çabuk kaybedilen ve ispatlanması gereken sosyal yapısını (bkz. kırılgan erkeklik) deneysel çalışmalarla incelemişlerdir. Bundan sonraki alt başlıkta yine erkeklik ideolojisi ve cinsiyet rolü çatışması konusundaki çalışmalardan beslenen "erkeklik" olgusunun kaygılı ve kırılgan yapısını anlamak üzere önerilmiş açıklamalar sunulacaktır.

\section{Kırılgan Erkeklik}

Erkeklik ideolojisi erkeklerin nasıl olması ve davranması gerektiğini belirtmektedir (Levant, 1996; O’Neil, 2008; Thompson ve Pleck, 1986). Pleck (1995) erkeklerin neden belli şekillerde davranıp, kendilerini başkalarının gözünde kanıtlamak durumunda olduklarını sorgulamıştır. Erkeklerin kendini sürekli kanıtlamasını söyleyen normlarla sosyalleştiğini, ancak kadınlar için kadınlığın kanıtını gerektiren normların olmadığını vurgulamıştır. Buna ek olarak, kadınlığın sosyal durumlara göre değişiklik göstermeyen; çocuk doğurabilmek gibi biyolojik olarak mümkün olan durumlar karşısında daha durağan bir statüye sahip olduğunu iddia etmiştir. Buna karşın erkeklerin, toplumun kendisine biçtiği "üstün" statüyü elde etmek için sürekli çabaladığını belirtmiştir; ancak bu önermeleri test etmemiştir.

Yazında daha önce belirtilen ancak deneysel yöntemlerle test edilmeyen erkekliğin ispat gerektiren bu yapısını Vandello ve arkadaşları (Vandello, Bosson, Cohen, Burnaford ve Weaver, 2008) Kirllgan Erkeklik Kuramı (Precarious Manhood Theory) çerçevesinde incelemişlerdir. Modern toplumlarda erkekliğin sosyal yapısını anlamak için özellikle deneysel yöntemlerle farklı çalışmalar yürütmüşlerdir. Vandello ve arkadaşları (Bosson ve Vandello, 2011; Vandello ve Bosson, 2013) kabile kültürlerinde erkeklerin kabilenin gözünde "gerçek bir erkek" olabilmek için avlanarak hayvan öldürme, sünnet olma, vücudunda yaralar açarak cesaretini ve korkusuzluğunu kanıtlama gibi farklı ritüellerden geçtiğini; modern toplumlarda ise bu gibi keskin ritüellerin yerini şiddet kullanmak gibi zararlı ve dolaylı yollara bıraktığını 
ve erkekliğin bu yollarla kanıtlanmaya çalışıldığını öne sürmüşlerdir. Erkekliğe kıyasla kadınlık ise biyolojik ve fiziksel özelliklerin gelişimi ve kendini göstermesiyle edinilen; statüsü toplumsal basamaklardan geçmeye birebir bağlı olmayan bir durum gibi algılanır. Birçok toplumda genç kızlıktan kadınlığa geçiş ritüelleri (örn., regl olma durumunda hediye alma ve kutlama (Burda, 2017) olsa bile, bu ritüellerde kadının kendini sosyal olarak kanitlamas1 beklenmez (Gilmore, 1990; Vandello ve ark., 2008).

Kırılgan erkeklik kuramı çerçevesinde toplumdaki erkeklik statüsünün ne kadar kırılgan olduğunu göstermeyi hedefleyen çalışmalarda şu önermeler incelenmiştir: İnsanlar erkekliği kadınlığa göre a) toplumsal olarak kazanması daha zor, b) kazanıldığında kaybetmesi daha kolay, c) tehdide açık ve başkalarının gözünde ispat gerektiren kayg1lı ve güvencesiz bir statü olarak görürler (Vandello ve ark., 2008; Vandello ve Bosson, 2013). Bu önermeler deneysel çalışmalarla test edilmiştir. Örneğin, katılımcılara Amerika'da sıkça kullanılan atasözlerinin arasında, erkekliği ve kadınlığı kazanmanın zorluğunu ima eden, araştırmacılar tarafından üretilmiş altı atasözü verilmiştir (örn., "Erkeklik/ kadınlık zor kazanılır, kolay kaybedilir"; "Erkek/kadın olmak yokuşlu bir yoldur"; "Oğlan/kız düşe kalka erkek/kadın olmayı öğrenir"). Katılımcılar cinsiyet farkı olmaksızın erkeklikle ilgili atasözlerine daha fazla katılmışlar, bu atasözlerini kadınlıkla ilgili olanlara kıyasla daha fazla sevmişler ve daha iyi anlamışlardır. Bu bulguya göre insanların erkekliği kadınlığa kıyasla daha zor kazanılan bir statü olarak alg1ladıkları ileri sürülmüştür (Vandello ve ark., 2008).

Kırılgan erkeklik kuramının (Vandello ve ark., 2008) önermesine göre, erkeklik zor kazanılan ama çabuk kaybedilen kırılgan bir yapıda olduğundan, erkekler cinsiyet içerikli tehdit durumunda kaygı ve stres hissederler. Vandello ve arkadaşları (2008), toplumsal cinsiyet rollerine dair bir testi uyguladıktan sonra erkek kat1lımcılara test sonuçlarının erkeklerin ortalamasına değil kadınların ortalamasına yakın çıktığını ve bu nedenle "kadınsı" olduklarını söyleyerek toplumsal cinsiyet tehditi yaratmışlardır. Daha sonra katılımcıların tehdit durumlarında kaygı yaşayıp yaşamadığı örtük kelime tamamlama yöntemiyle test edilmiştir. Örneğin, _AY _ I kelimesini tamamlamaları istenmiştir. Bu kelime hem "saygı" hem de "kaygı" olarak tamamlanabilir. Araştırmacılar bu durumdan tehdit algılayanların boşlukları kaygı belirten kelimelerle tamamladıklarını; erkeklerin aldıkları (sahte) "kadınsılık" test puanının başkaları ile paylaşılması fikrinden kadınlara göre daha fazla rahatsız olduklarını ve erkeklerin gelecekte daha iyi bir puan alabileceklerini belirttiklerini bulmuşlardır. Bu bulgularına dayanarak Vandello ve ark. (2008) toplumsal cinsiyet tehditlerinin erkeklerde güçlü bir şekilde anksiyete ile ilintili duygular yarattığını belirtmişlerdir. Sosyal yaşamda erkeklikle ilintili tehdit unsurları iş kaybı, ailesine bakamama ve evi geçindirememe olarak da belirtilmektedir (Gilmore, 1990).

Kırılgan erkeklik kuramının diğer önermesine göre, erkekler erkekliklerini korumak ya da geri kazanmak adına daha riskli ve saldırgan davranışlar gösterirler. Saldırgan davranışlar ve fiziksel olarak sert olmak erkeklik ideolojisinin öngördüğü özellikler olduğundan (Brannon ve Juni, 1984; Luyt, 2005; Mahalik ve ark., 2003; Thompson ve Pleck, 1986); tehdit algilayan erkekler sorgulanan erkekliklerini finansal açıdan riskli davranışlar (Parent, Kalenkoski ve Cardella, 2018; Weaver, Vandello ve Bosson, 2013), saldırganlık, şiddet ve öfke göstererek (Bosson, Vandello, Burnaford, Weaver ve Wasti, 2009; Weaver, Vandello, Bosson ve Burnaford, 2010) yeniden kurgular (Jakupcak, Lisak ve Roemer, 2002). Örneğin, erkeklere kadınsı kokan el kremi sürülerek tehdit yaratıld1ktan sonra, bu erkeklerin kumar oyununda daha fazla risk aldığ1 görülmüştür (Weaver ve ark., 2013). Başka bir çalışmada (Bosson ve ark., 2009) deney grubundaki erkeklere oyuncak bebek saçı ördürürken, kontrol grubundaki erkeklere halat ördürerek ilk gruptakiler için erkeklik tehdidi yaratmışlar; sonrasında ise kum torbası yumruklamak veya yapboz yapmak gibi aktivitelerden birini seçmelerini istemişlerdir. Saç örerek erkeklikleri tehdit edilen erkekler hem kum torbasını yumruklamay1 seçmişler; hem de kum torbasını daha kuvvetli yumruklayarak erkeksi özellikler göstermeye ve erkekliklerini başkalarının gözünde tekrar kazanmaya çalışmışlardır. Diğer çalışmalarda erkeklikleri tehdit edilen kişilerde riskli finansal davranışların ve saldırganlığın kaygı düzeyini düşürdüğünü ve erkekliğin tekrar kazanılmasında etkin bir yol oynadıklarını göstermiştir (Parent ve Moradi, 2009). Benzer şekilde, cinsiyet tehditi alan erkeklerin saldırganlık bilişlerinin daha fazla olduğu; acıya daha çok katlandıkları ve cinsiyet rol tutarsızlığını daha kolay algıladıkları görülmektedir (Berke, Reidy, Miller ve Zeicher, 2016).

Erkeklik çalışmalarından elde edilen bilgilere göre toplumda kadınsı görülen davranışlarda bulunmak erkekler için en önde gelen "tehdit" unsurlarında biridir. Hatta kadınsı görünen hastalıklarla teşhis edilme ihtimali bile erkeklerde bir tehdit algısı yaratmaktadır. Anoreksiya ve bulimia nervosa gibi yeme bozuklukları, majör depresyon, genel kaygı bozukluğu gibi "kadınsı" bulunan hastalıklarla teşhis edildiğini hayal eden erkekler; başkalarının artık kendilerini daha az erkek göreceğini ve bundan çok rahatsızlık duyacaklarını belirtmişlerdir (Michniewicz, Bosson, Lenes ve Chen, 2015). Bununla birlikte erkekler, dans etmek, moda dergileri okumak, birinin saçlarını yapmak gibi kadınsı davranışları hayal ettiklerinde bile hissettikleri tehdit artmış ve başkalarının 
kendilerini eşcinsel olarak göreceğinden endişelenmişlerdir (Bosson, Prewitt-Freilino ve Taylor, 2005). Hatta, iş tercihi yapması istenen erkek katılımcılar kadınsı algılanan esnek çalışma olanaklarını reddederek kadınsılıktan kaçınmışlardır (Vandello, Hettinger, Bosson ve Siddiqi, 2013).

Üstte belirtilen çalışmalar, erkekliğin sağlam bir zeminde inşa edilmediğini ve sürekli kendisine biçilen "erkeklik" statüsünü hak ettiğini göstermek adına ispat çabasına girdiğini göstermektedir. Ancak bazı eleştirel yazılar (Addis ve Schwab, 2013) sadece erkekliğin değil, hem kadınlığın hem de erkekliğin kırılganlığından bahsedilebileceğini ileri sürmüşlerdir. Bu araştırmacılara göre toplumsal cinsiyet, tanımı gereği sosyal icralar bütünüdür ve kadınlık da erkeklik de toplumsal dinamiklerle şekillenen ve icra edilen statülerdir. Kadınlık statüsünün erkekliğe kıyasla daha kolay elde edildiği gibi bir yanılsamaya düşmemek adına, kadınlığa geçişi ve kadınlık statüsünü hem kadınların hem de toplumdaki diğer bireylerin nasıl algıladığını araştıran daha fazla çalışmaya ihtiyaç vardır (Addis ve Schwab, 2013; Chrisler, 2013).

Ek olarak, kırılgan erkeklik kuramı, erkekliğin ne kadar kırılgan ve krize açık olduğunu göstermektedir. Erkeğin başkalarının gözündeki statüsü norm dışı bir davranışla tehdit edilebildiğinden (örn., feminen görünmek) ve bu da algısal olarak erkekliğin yitirilmesine yol açtığından (örn., Türkiye'de "adam değilsin" algısı) (Bosson ve Vandello, 2011) erkeklerin daha riskli ve saldırgan davranışlar içine girdiği görülmektedir. Bu durum erkeklerin koruyucu, kollayıcı ve kadın namusunun sahibi olarak algılandığı namus kültürlerinde de görülmekte (Glick, Sakallı-Uğurlu, Akbaş, Metin Orta ve Ceylan, 2016; Sakall1-Uğurlu ve Akbaş, 2013); başkalarının saldırısıyla zarar görmüş veya kirlenmiş olarak algılanan namusunun tamir edilmesi adına saldırgan davranışlar göstermesi kabul edilebilmektedir (Bosson ve Vandello, 2011; Vandello, Cohen, Granson ve Franiuk, 2009). Görüldüğü üzere, kırılgan erkeklik gerek bireysel kaygının yükseltmesiyle gerekse de diğer birey ve gruplara (örn., kadınlar ve geyler) yönelik çeşitli yıkııı davranışlara yol açmasıyla daha ayrıntılı incelenmesi gereken bir olguya işaret etmektedir. Bu nedenle bir sonraki başlıkta, erkekliğin bireysel olarak erkeklere ve diğerleriyle olan ilişkilerine olan olumsuz etkileri gözden geçirilecektir.

\section{Ayrımcılık Bağlamında Erkekliğin Yıkıcı Çıktıları}

Erkeklik ideolojisinin yaptırımlarıyla erkekler, hem psikolojik ve fiziksel sağlıklarıyla ilgili bireysel sorunlar hem de kadınlar ve eşcinseller gibi diğer gruplara ilişkin tutum ve davranışları, yakın ilişkileri ve kişiler arası ilişkileri bağlamında sorunlar yaşarlar. Cinsiyet rollerine uyma konusundaki tutumları, kişilerin dav- ranışlarını farklı şekillerde etkiler. Geleneksel cinsiyet rollerine bağlı olan kişiler bu rollere uyma çabası içinde stres yaşayıp, saldırganlık, psikolojik veya fiziksel sağlık sorunları gibi farklı yıkıcı çıktılarla yüzleşirler (örn., O’Neil, 2008). Bu bölümde erkekliğin yıkıcı çıktıları bireyin kendisine ve diğerlerine verdiği zararlar olarak iki ayrı alt başlık altında ele alınacaktır.

\section{Bireyin Kendisine Verdiği Zararlar}

Toplumsal normları yansitsa da erkeklik ideolojisi, cinsiyet kalıpyargıları ve erkeksi olma beklentisi bireyler için bazı olumsuz sonuçlar doğurabilmektedir. Tablo 1'deki farklı ölçekler kullanılarak yapılan çalışmalarda gerek erkeklik normlarını gerekse kalıpyargıları karşılamadığını düşünen erkekler birçok olumsuz bireysel çıktıyla yüzleşmektedir. Yapılan çalışmaların bazılarına göre, erkeklik normlarına uyum arttıkça (Parent ve Moradi, 2009) kaslarından hoşnutsuzluk (Frederick ve ark., 2017), yeme bozuklukları ve vücut yağlarından şikayet etme gibi fiziksel görünüm ve fiziksel sağlık ile ilgili sorunların arttığ1 görülmektedir (Griffiths, Murray ve Touyz, 2015). Erkeksi cinsiyet rolü stresi yaşayanlar ise egzersiz yapmama ve diyet yapmama gibi sağlıklarına zararlı davranışlar göstermektedirler (Eisler, Skidmore ve Ward, 1988). Ek olarak, erkeksi cinsiyet rolü stresi yüksek ve cinsel olarak aktif olan üniversite öğrencileri cinsel ilişkilerinde prezervatif kullanma olasılıklarının düşük olduğunu belirtmişler (Pleck ve ark. 1993; Thompson ve ark., 1985) ve bu şekilde cinsel sağlıklarını riske atmışlardır.

Fiziksel görünüm ve fiziksel sağlığın yanı sıra çalışmalar psikolojik sağlıkla ilgili sorunların oluşabileceğini göstermektedir. Örneğin, Maçoluk Ölçeği kullanılarak yapılan bir çalışmada maçoluk düzeyi yüksek erkeklerin benlik saygınlıkları da düşük bulunmuştur (Neff, Prihoda ve Hoppe, 1991). Paralel olarak, Cinsiyet Rol Çatışması Ölçeği'nden yüksek puan alan kişilerin daha fazla psikolojik rahatsızlık yaşadıkları (Wester, Vogel, Wei ve McLain, 2006) ve yakınlıktan korktukları (Good, Hepper, Hillenbrand-Gunn ve Wang, 1995) görülmüştür. Benzer şekilde, erkeksi cinsiyet rolü stresi yüksek olan erkeklerin kendilerini sözel olarak ifade edemedikleri (Saurer ve Eisler, 1990); kendilerini açmakta sorun yaşadıkları ve Tip A davranışları gösterdikleri bulunmuştur (Thompson ve ark., 1985). Cinsiyet rolü çatışması yaşayan erkeklerin düşük benlik saygısı, yüksek kaygı ve depresyon gibi psikolojik sağlığı tehdit eden sonuçlarla yüzleştiği görülmüştür (bkz. O’Neil, 2008). Ek olarak, mantıksız sosyal korkuları, kızgınlık ve anksiyeteleri yükselmiştir (bkz. Baugher ve Gazmararian, 2015; Gallagher ve Parrott, 2011; McCreary ve ark., 1996).

Ayrıca, cinsiyet rol çatışması yüksek olan erkekler, başkalarından yardım arama konusunda olumsuz tutumlara sahiptir (White, 2002). Erkek rol normlarını benim- 
seme erkeklerin psikolojik yardım aramasına bariyer oluşturmaktadır (Yousaf, Popat ve Hunter, 2015). Erkekler diğerlerinden psikolojik yardım almak yerine alkol tüketimi gibi sağlıklarını tehdit edici davranışlara yönelmektedir. Örneğin, Whitley, Madson ve Zeiggler-Hill (2018) erkeklik normlarına yüksek düzeyde uyan ve kendini koruma stratejilerini düşük düzeyde kullanan erkeklerin daha fazla alkol kullandığını bulmuştur. Benzer şekilde, erkeksi cinsiyet rol stresi arttıkça (Swartout ve ark., 2015) alkol kullanımı, alkol sorunları ve öfke de artış görülmüştür.

Fiziksel ve psikolojik sorunlara ilaveten, erkeklik normlarının eğitim alışkanlıklarını etkileyebileceği görülmektedir. Örneğin, bir çalışmada erkeklerin erkeklik normlarına uyumu arttıkça daha yüzeysel bir öğrenme şeklini (örn., sadece dersin gerekliliklerini yerine getirme çabası vb.) benimseme ihtimalleri artmaktadır (Marrs ve Sigler, 2012).

Tüm bu çalışmalardan anlaşıldığ1 üzere, erkeksilik/kadınsılık, maçoluk, cinsiyet rol çatışması ve erkeksi cinsiyet rol stresi gibi konulardaki farklı ölçeklerle yap1lan çalışmalarda erkeklerin, gündelik yaşantılarında toplumdaki statülerini sorgulatabilecek pek çok durumdan rahatsızlık duyup, kaygı ve stres kaynaklı sağlık, psikolojik ve akademik problemler yaşadıkları görülmektedir. Kisacas1, buyurgan kalıpyargilar ve yasaklayıcı toplumsal cinsiyet normları erkeklerin sosyalizasyon süreçlerinde olumsuz çıktılara neden olabilmektedir (Wester, Vogel, O’Neil ve Danforth, 2012).

\section{Bireyin Diğerlerine Verdiği Zararlar}

Erkekliğin yıkıcı çıktılarından diğeri ise bireyler arası ilişkilerde erkeğin diğerlerine verdiği zararlardır. $\mathrm{Bu}$ zararların başında şiddet ve saldırganlık gelmektedir. Örneğin, Bem'in Cinsiyet Rol Envanteri'nde erkeksilik düzeyi yüksek olan kişilerin yakın ilişkilerinde şiddet kullandığı (Bernard, Bernard ve Bernard, 1985; Thompson, 1990) ve saldırgan erkeklerin kadınsılık düzeylerinin düşük olduğu (Worth, Mathews ve Coleman, 1990) bulunmuştur. Benzer bir şekilde, erkekler erkek rol normlarını daha fazla benimsedikçe (Thompson ve Pleck, 1986) yakın ilişkilerinde partnerlerine karşı kullandıkları psikolojik şiddet (Good, Hepper, Hilllenbrand-Gunn ve Wang, 1995; Jenkins ve Aube, 2002; Moore ve ark., 2008), güç kullanma ve eşcinsellik korkuları (Thompson, Grisanti ve Pleck, 1985) artmaktadır. Maço Ölçeği ile ölçülen cinsiyetçi tutumların yüksek olması ile eşcinsellik korkusu ve sosyal olarak sorumsuzluk içeren davranışlarla ilintili bulunmuştur (Good, Borst ve Wallace, 1994).

Paralel olarak, erkeksi cinsiyet rolü stresi ile yakın ilişkilerde şiddet (Franchine, Eisler ve Moore, 2001), kadınlara ve geylere yönelik şiddet arasında olumlu bir ilişki bulunmuştur (bkz. Baugher ve Gazmararian, 2015). Genel olarak, cinsiyet rol stresi ile yakın ilişkilerdeki şiddet arasında orta düzeyde pozitif bir korelasyon olduğu belirtilmiştir (Moore ve Stuart, 2005). Ayrıca, özellikle kadınsılıktan uzak durma ve statü sahibi olma ideolojilerini benimseyen erkeklerin, hissettikleri erkek rolleri stresi sebebiyle partnerlerine daha fazla fiziksel şiddet uyguladıkları; eğer alkol kullanıyorsa bu şiddetin daha da arttığ1 görülmüştür (Lisco, Leone, Gallagher ve Parrott, 2015). Benzer şekilde, klinik düzeyde saldırgan olan erkekler ile yapılan bir çalışmada, erkeksi cinsiyet rol stresinin farklı faktörlerinin psikolojik şiddet (performans başarısızlığı faktörü), cinsel korkutma (fiziksel yetersizlik faktörü) ve yaralama (entellektüel başarısızlık faktörü) ile ilişkili olduğu görülmüştür (Moore ve ark., 2008).

Ayrıca, erkekliklerine yönelik tehdit algılayan erkekler farklı gruplara karşı birçok ayrımcı ve düşmanca tutumlar ve davranışlar sergilemektedir. Örneğin, toplumsal cinsiyet tehdidi alan erkekler sonrasında eşcinselleri hedef alan homofobik ve cinsiyetçi esprileri daha komik bulmuş ve hatta bu tarz şakalar yaptığında patronlarının onlar hakkında daha olumlu bir izlenimi olacağını düşünmüşlerdir (O'Connor, Ford ve Banas, 2017). Benzer şekilde, erkekler, erkeksi olmayan erkeklerden hoşlanmamakta (Schmitt ve Branscombe, 2001); kendi beden ve cinsel güçlerini abartmakta (Cheryan, Cameron, Katagiri ve Monin, 2015); kadınları taciz etmekte (Maass, Cadinu, Guarnieri ve Grasselli, 2003); ve deney ortamında daha güçlü elektrik şoku vermektedirler (Holmes, 1971). Ayrıca, kadınsı olduğu söylenen erkekler başkalarının kendisi hakkında olumsuz düşüneceğinden fazlaca rahatsız olmakta; buna bağlı olarak öfke seviyeleri artmakta; toplumdaki erkek üstünlüğünü daha fazla savunmakta (Dahl, Vescio ve Weaver, 2015) ve geleneksel cinsiyet rollerini daha fazla desteklemektedir (Kosakowska-Berezecka ve ark., 2016). Kisacas1, erkekler bazen saldırganlık gibi daha doğrudan yollarla bazen de fayda görmeye devam edecekleri toplumsal sistemi destekleyerek daha dolaylı yollarla erkeklik statüsünü geri kazanmaya ya da korumaya çabalamaktadır.

Şiddeti erkeklik ideolojisinin bir çıktısı olarak kullanmanın yanında, tanık oldukları şiddete müdahale etme durumları da erkeklik nomları ve stresi ile ilişkili görülmektedir. Örneğin, Leone, Parott, Swartout ve Tharp (2016) Erkek Rol Normları Ölçeği ve Erkeksi Cinsiyet Rolleri Stresi Ölçeği’ni kullanarak cinsel saldırılar durumunda seyirci müdahalesi arasındaki ilişkiyi ele almışlardır. Buna göre, statü normlarını benimseme (erkeklerin toplumda statü sahibi olması gerektiği) ile seyirci müdahalesi arasında önemli bir ilişki bulunmuştur. Erkekler diğerlerinin saygısını kazanacağını düşündüklerinde cinsel saldırılara müdahale etme tutumları 
daha olumludur. Öte yandan, sertlik normunu benimseyen erkekler cinsel saldırılara müdahale konusunda çekingen davranacaklarını belirtmişlerdir. Statü normlarını benimseyen ve erkeksi cinsiyet rol stresi yüksek olan erkekler müdahale sonuçlarını olumlu algılayıp seyirci müdahalesine olumlu bakmaktadırlar.

\section{Erkeksilik/Erkeklik Konusunda Türkiye'de Yapılan Çalışmalar}

Türkiye'de erkeklik, gündelik dile bile oldukça fazla sirayet etmiş bir olgudur ve bu şekilde insanların toplumsal cinsiyet algılarını da şekillendirir. Örneğin, "adam gibi adam", "adamın hası", "adamın dibi" "koç gibi erkek" ve daha nicesi erkekliğin gündelik yaşantımızdaki en basit temsilini gösterir. Bu tarz söylemler aslında Türkiye'de erkekliğe verilen önemi ve farklı erkeklikler arasında bir kıyaslama olduğunu belirtir. Türkiye'de erkeklik çalışmaları geç kalınmış bir alan olarak görülse de (Atay, 2004), ataerkil bir kültürde erkekliğin sorgulanması ve erkeklik ideolojisinin ilişkili olduğu değişkenlerin araştırılması oldukça önemlidir. Türkiye'de daha çok sosyoloji, antropoloji, edebiyat ve siyaset bilimi çalışmalarıyla şekillenmiş ve sonrasında psikoloji yazınında da güncel yerini almaya başlamış olan erkeklik çalışmalarının içeriği ve kapsamı bu başlıkta genellikle psikoloji alanından araştırmalara yer verilerek sunulacaktır.

Türkiye'de cinsiyet rolleri ve kalıpyargılar konusunda bazı çalışmalar mevcuttur. Örneğin, Kandiyoti (1978) doçentlik tezi kapsamında Cinsiyet Rolleri Kalıpyarg1 Ölçeği'ni geliştirmiştir. Bu ölçekte 22 sıfat (örn., duygusalllık, fedakarlık, sertlik, saldırganlık, atılganlık ve katılık) bulunmaktadır. Daha sonraki yıllarda, Baykal (1988) bu ölçeği öğrenci örnekleminde uygulayarak kendilerini değerlendirmelerini istemiş ve bu kalıpyargılar ile kendilerini kabul etme arasındaki ilişkiyi incelemiştir. Ayrıca, Dökmen (1991), Bem'in Cinsiyet Rolleri Envanteri'ni Türkçe'ye uyarlamıştır. Araştırmacılar biyolojik farkl1lıklar temelinde ortaya çıkan cinsiyete dayalı iş bölümü ve rolleriyle bağlantılı olarak aile ekonomisi, istihdam ve aile yapısı konusunu ele almışlardır (Dedeoğlu, 2000). Kalıpyargilar konusundaki en güncel çalışmada ise, Sakall1-Uğurlu, Türkoğlu ve Kuzlak (2018a) Türkiye toplumunun genel olarak "kadın" ve "erkek" kavramlarını nasıl tanımladıklarını serbest cevap verme yöntemiyle ele almışlardır. Erkekler kıskanç, güçlü, bencil, duygusal, hırslı, kızgın, kaba, çocuksu, mantıklı, çalışkan, zeki, dürüst, cesur ve koruyucu olarak tanımlanmıştır. Farklı bir çalışmalarında Sakallı-Uğurlu, Türkoğlu, Kuzlak ve Gupta (2018b) Türkiye'de evliliğe verilen önemi göz önünde bulundurarak evliliğin erkek ve kadın kalıpyargıları üzerindeki farklılaştırıcı etkisini araştırmışlardır. Erkek kalıpyargılarına bakıldığında evli erkeklerin bekar erkeklere kıyasla sayısal olarak daha fazla kalıpyargıyla nitelendikleri bulunmuştur. Bekar erkekler genellikle dış görünüşleri (yakışıklı olma) ve çapkın, sorumsuz, şımarık, çocuksu olma gibi olumsuz kişilik özellikleriyle daha fazla tanımlanırken; evli erkekler ise ağırlıklı olarak toplumsal cinsiyet rolleri ile tanımlanmıştır. Buna göre evli erkekler, aile babası, sorumluluk sahibi, çalışkan, fedakar, koruyucu aile reisleri olarak resmedilmiştir. Bekar ve evli erkek kalıpyargılarındaki en büyük ortaklık ise her iki grubun da baskın, üstün, kızgın, şiddete yatkın, serbest ve özgür olarak tarif edilmesidir ki bu kalıpyargılar erkeklerin toplumsal iktidarının devamına işaret etmektedir.

Kalıpyargı çalışmalarıyla tutarlı olarak, Türkiye'de erkekliğe dair belli başlı dönüm noktaları bulunmaktadır. Aileler için ilk dönüm noktası bir erkek çocuk sahibi olmak iken (Ataca, Kağıtçıbaşı ve Diri, 2005), o çocuk için sünnet (Kırıml1, 2010), ilk cinsel deneyim (Selek, 2008), askerlik (Sünbüloğlu, 2013), baba ile olan ilişkiler, evlenip aile kurma, aile resiliği (Sancar, 2009) ve babalık (Zeybekoğlu, 2013) bu toplumsal süreçlerin en belirgin olanlarıdır. Benzer şekilde, Bolak-Boratav ve arkadaşlar1 (2017) "Erkekliğin Türkiye Halleri” kitabında "Türkiye'de evli erkeklerin hem erkek olarak yetişirken geçtikleri gelişimsel süreçleri hem de erkeklik öğretilerini nasıl edindiklerini ve hayata geçirdiklerini daha iyi anlamak" (p. 9) adına yaptıkları kapsamlı çalışmayı sunmuşlardır. Bu çalışmada erkek katılımcılara erkek olduklarını ilk ne zaman hissettikleri sorulmuştur. Bu soruya en çok verilen cevap "hep hissetmişimdir" (\% 38.45). Daha sonra, sirasıyla "sünnet olduğumda" (\%20.60), "askerlikte" (\% 14.95), "ilk cinsel tecrübemde" (\% 12.85), "ilk aş1k olduğumda" (\%2.70), "çocuğum olduğunda" (\%2.55), "ilk maaşımı aldığımda" (\%2.30) ve "ergenlik çağında" (\%2.25) cevapları verilmiştir. Bulgulara göre, Türkiye'deki erkeklerin çoğu erkek olduklarını hep hissetmişlerdir. $\mathrm{Bu}$, erkek olmak için bir nedene ve açıklamaya gerek yoktur anlamında ise erkek doğmuş olmak çoğu erkek için erkek hissetmeye yetmektedir. Bu bulgular bir yandan erkekliğin farklı sosyal basamaklardan geçerek bazı çabalar sonucu edinildiğini söyleyen kırılgan erkeklik kuramı ile örtüşürken; diğer yandan erkekliğin verili ve hissedilen bir durum/statü olup olmadığg sorularını da tekrar gündeme getirmektedir. Kır1lgan erkeklik kuramının (Vandello ve ark., 2008) sorduğu bu soruları doktora tezi kapsamında Türkiye'de yeniden test eden Türkoğlu (2019), erkekliğin (kadınlığa kıyasla) bazı aşamalardan geçerek kazanılan bir statü olduğunu göstermiştir. Ancak Amerikan örnekleminden farklı olarak, çocukluktan erkekliğe (ve kadınlığa) geçiş, sosyal olduğundan çok fiziksel değişimlerden geçerek tamamlanan bir süreç olarak görülmüştür. Buna rağmen erkekliğin kaybı, Türkiye'de de işini kaybetme vb. gibi sosyal başarısızlıklara atfedilmektedir. 
Üstünel (2010), 17 üniversite öğrencisiyle yaptığ1 görüşmelere dayanan yüksek lisans tezinde genç erkekliklerin Türkiye'nin farklı bölgelerde (batı-doğu) veya kente/köyde doğup büyümüş olmaya göre erkeklik kimliklerini farklı şekillerde inşa ve icra ettiklerini göstermiştir. Coğrafi bölgelere, ailede özellikle babaları ile olan ilişkilerine ve arkadaş ilişkilerine göre farkl1lıklar taşısa da, tüm bu erkekliklerin iktidar/güç sahibi olma; sorumluluk taşıma; sosyal prestij ve erkeksi ilgi alanları çatısında benzer görüşler paylaştıkları görülmüştür. Ek olarak, Türkoğlu (2013b), idealleştirilen sosyal prestijin evli veya bekar olması fark etmeksizin tüm erkekler için "bir iş sahibi olmak”tan geçtiğini 21 erkekle yapılan yüzyüze görüşmeler aracılığıyla göstermiştir. Genç, yaşlı, esnaf, beyaz yaka, öğrenci gibi farklı erkeklikleri temsil eden örneklemin tamamı Türkiye'deki erkekliği, çalışıp iş sahibi olmak ve bunun getirdiği sorumluluğu taşıyabilme becerisi olarak görmektedir. Sancar (2009)'ın alan çalışmasında da gösterdiği gibi, bu sorumluluk söylemi sosyo-ekonomik seviyesi düşük olan erkeklerde daha fazla ön plana çıksa da; işi ve dolayısıyla sorumluluğu kaybetme riski her seviyeden erkek için statü kaybı ve gözden düşme anlamına gelmektedir (Türkoğlu, 2013b).

Benzer ideoloji, yazında sıkça kullanılan Toplumsal Cinsiyet Rol Çatışması (O’Neil ve ark., 1986) ve Erkek Rol Normları Ölçeği'nin (Thompson ve Pleck, 1986) Türkçe'ye uyarlama çalışmalarında da doğrulanmıştır. Erkek üniversite öğrencileriyle yapılan çalışmada Türkiye'deki erkeklerin de erkek rol normlarını statü, kadınsılıktan kaçınmak, sertlik üzerinden tanımladıkları görülmüştür. Ayrıca, başarı, güç, rekabet; kısıtlayıcı duygular; erkekler arası ilişkilerde duyguları göstermeme ve aile-iş ilişkilerinde çatışmalar yaşadıkları görülmektedir (Lease, Çiftçi, Demir ve Boyraz, 2009). Erkeklerin erkeklik rollerine dair yaşadığı çatışmalar, aslında norm dişında kalmaya, rollerine ve erkek kimliklerine yöneltilen herhangi bir tehdide ne kadar açık olabileceklerine işaret etmektedir. Örneğin, doktora tezinde Elgin (2016), erkeklik ideolojisinin, namusa verilen değer ve erkek-erkeğe hakarete karşı tepki arasında aracı değişken olarak rol oynadığını göstermiştir. Benzer şekilde, Türkoğlu (2013a) yüksek lisans tezinde Türkiye'de erkeklerin kadınlardan aşağıda olma; koruyucu, karar verici ve aile reisi rolü; ve sert/ erkeksi görünüşlerini hedef alan durumlarda tehdit algıladıklarını ve fazlaca rahatsızlık duyduklarını göstermiştir. Ayrıca, bu durumlardan algılanan tehdit, erkeklik ideolojisi ve kadına yönelik şiddeti onaylayan tutumlar arasında aracı değişken rolü oynamıştır. Erkeklik ideolojisini benimseyen erkekler, aile reisliği statülerine daha fazla tehdit algılamışlar ve tehdit algıları arttıkça kadına yönelik şiddeti daha fazla onaylamışlardır.
Lease ve arkadaşları (2013) Türkiye, Amerika ve Norveç kültürlerinde erkek rol normlarını benimseme ve romantik ilişkiler arasındaki ilişkiyi incelemişlerdir. Bulgulara göre Türkiye'deki erkekler statü, kadınsılık karşıtlığı ve sertlik bağlamında ölçülen erkek rol normlarını ortalamanın üzerinde benimsedikleri ve bu normlara bağlılıkları arttıkça ilişkilerine daha az duygusal yatırım yaptıkları görülmüştür. Ayrıca, bu üç kültür karşılaştırıldığında toplumsal cinsiyet eşitliğini gündelik hayatın her alanında uygulayan ve feminist mücadelede erkekleri partner olarak gören Norveç'in yanında Türkiye, erkeklik ideolojisini Amerika ile benzer seviyelerde benimsemekte ve bu geleneksel ideolojiyi sürdürmektedir. Bu ideolojiyi benimsemenin evlilikteki uyum üzerindeki etkisini araştıran Kalkan ve Odacı (2017) ise, evlilikte erkeklik ideolojisi ne kadar benimsenirse evlilik kalitesinin o ölçüde azaldığını göstermişlerdir. Buna göre, erkekler kadınsılıktan ne kadar kaçınır, duygu ifadesini kısıtlar, öfkelenir ve sekse yönelik olumsuz tutumlar beslerse, evlilik ilişkisinin kalitesi o ölçüde düşmekte ve aile bütçesinden boș zaman aktivitelerine kadar pek çok konuda daha az uzlaşmaya neden olmaktadir.

Geleneksel erkeklik ideolojisi Türkiye'deki genel varlığını sürdürse de, farklı sosyo-ekonomik sınıflardan erkeklerin değişen toplumda kendi erkekliklerine dair bazı çelişkiler yaşadıkları da görülmektedir. $\mathrm{Bu}$ konuyu ele alan Bolak-Boratav, Okman-Fişek ve Eslen-Ziya (2014), Türkiye'nin yedi bölgesinden temsili olarak seçilen düşük, orta ve yüksek sosyo-ekonomik seviyelerden 50 evli erkekle görüşmeler yapmışlardır. Babalarının otoriter ve katı oluşundan yakınan bu erkekler, kendi çocuklarıyla daha sevecen ve duygusal ilişkiler kurmayı istemekte ve bilinçli olarak otoriter bir baba olmaktan kaçınmaktadır. Ancak, yine de eşitlikçi bir baba olmayı başaranların oranı oldukça düşük görülmüştür. Eşleriyle olan ilişkilerine bakıldığında alt sınıftan erkekler eşlerinin kendi otoritelerine saygı duymasını ve evin dışındaki pek çok davranışı için eşinin kendisinden izin almasını beklemekteyken; orta s1nıf erkekler eşleriyle daha esnek bir anlaşma içerisinde olup, "evin reisi" otoritelerini zedelemediği müddetçe ev işlerini de paylaşmışlardır. Ancak, sosyal sınıf fark etmeksizin, eşleriyle duygusal yakınlık kurduklarını ve hemen her şeyi paylaştıklarını söyleseler de maddiyat ile ilgili sıkıntıları konuşmakta zorlandıkları görülmüştür. Sınıfsal farklılıklar görülse de Türkiye'deki evli erkeklerin geleneksel, eşinden ve ailesinden saygı bekleyen statü sahibi bir erkek olma istekleri olduğu görülmüştür. Ancak kendi babalarından farklı olarak daha esnek ve iletişime açık olma istekleri değişen Türkiye toplumunda evli erkeklerin değişimle olan imtihanı şeklindedir. 


\section{Sonuç ve Öneriler}

Sosyal psikologlar olarak erkeklik olgusunu anlamak ve erkekliğin bireyler ve gruplar arası ilişkileri nasıl düzenlediğini sistemli bir şekilde göstermek, özellikle Türkiye'de bu alanda yapılacak araştırmalara kaynak sağlamak adına kolaylıklar ve katkılar sağlayabilir. $\mathrm{Bu}$ derleme çalışmasında birbiri yerine de kullanılabilen erkeksilik, erkeklik, erkeklik ideolojisi gibi kavramlar ve bunlarla ilgili çalışmalar okuyucuya sunulmuş ve bu kavramların toplumsal cinsiyet temelli kalıpyargı, önyargı ve ayrımcılık ile ilişkisi gösterilmiştir. Kalıpyargılar açısından bakıldığında, alandaki çalışmalar genel cinsiyet rolleri açısından hem kadın hem de erkekleri ele alarak ilerlemiştir. Cinsiyetçilik çalışmalarında kalıpyargılarla ilerleyen kuramlar daha çok "kadın" konusuna odaklanmıștır. Kalıpyargıların içeriği kuramı (Fiske ve ark., 2002) farklı grupların yanı sıra farklı kadın gruplarına ilişkin kalıpyargıları da incelemiştir. Benzer şekilde, Türkiye'den araştırmacılar (Aktan ve Bilim, 2016) alanda farklı kadın gruplarına (tiplerine) ilişkin kalıpyargıları kalıpyargıların içeriği kuramına göre irdelemiștir. Kadın alt gruplarına (örn., iş kadını, akademisyen, feminist, ev hanımı, gündelikçi, tiki, hayat kadını vb.) yönelik kalipyargı içeriklerinin yetkinlik ve sevecenlik üzerinden tanımlanabileceği vurgulanmış ve birçok kadın grubuna yönelik kalıpyargıların karma içerikli olduğu; bu kalıpyargıların statü-yetkinlik ve yarıșmacılık-sevecen(siz)lik ile iliş̧kili olduğu gösterilmiştir. Ancak, evli-bekar ayrımı (Sakall1-Uğurlu ve ark., 2018b) dışında erkek gruplarına/tiplerine ilişkin kalıpyargılar çalışılmamıştır. Türkiye'de farklı erkek tiplerinin neler olabileceği, bunların nasıl algılandığı ve bu farklı tiplerin erkeklik algısına etkileri gibi farklı konuların ele alınması yerinde olacaktır.

Kalıpyargılarının bu önemi kendisini tutumlar ve ayrımcılıkta da belirgin bir şekilde göstermektedir. Örneğin, Bem'in (1974) erkeksilik konusunda yaptığı çalıșmasının tutumlar konusundaki çalışmaları çokça etkilediği görülmektedir. Güncel çalışmalar (Kochel ve ark., 2016) erkeksiliği Bem'in çalı̧̧masından esinlenerek ölçmeye çalışmaktadırlar. Toplumsal cinsiyet rollerinden beslenen bu tutum çalışmaları erkeklerin nasıl olması/olmaması gerektiği konularının ne kadar onaylandığını ele alarak erkeklik ideolojisi kavramının ortaya çıkmasına önayak olmuştur. Tablo 1'deki ölçek bilgilerinden de anlaşılacağ 1 üzere erkeklik, statü ve/veya başarı, sertlik, ataerkil öğretilerin kabulü, kadınsılıktan kaçınma ve eşcinsellikten korkma/nefret, kendine güven, saldırganlık, cinselliğe ilişkin tutumlar ve duygusallığın kısıtlanması gibi unsurlar ile belirlenmektedir. Nitel ya da korelasyonel çaıışmaların açıklamalarını temeline oturtarak ilerleyen ve var olan korelasyonel ya da ölçek çalışmalarını deneysel yöntemle inceleyen kırılgan erkeklik kuramına göre de erkeklik toplumsal olarak kazanması daha zor; kazanıl- dığında kaybetmesi daha kolay ve tehdit edildiğinde başkalarının gözünde yeniden "erkek" olabilmek için sosyal kanıtlar gerektiren kaygılı ve güvencesiz bir statü olarak algılanmaktadır (örn., Vandello ve Bosson, 2013).

Yazında da görülebileceği gibi, normatif yaklaşıma göre toplumsal olarak tek bir tür erkeklikten ziyade yerel, bölgesel veya toplumsal ölçekte farklı tezahürleri olan farklı erkeklikler vardır (Connell, 1995; Üstünel, 2010). Erkeklik ideolojisinin bazı bileşenleri her erkek grubu tarafından eşit şekilde benimsenmeyebilir. Connell (1995) erkeklik çalışmalarına yön veren kitabında, erkekliğin tekil ve durağan bir yapısı olmadığından; aksine zamana, duruma, yaşam koşullarına ve tarihsel dinamiklere göre değişen farklı erkeklikler olduğundan bahseder. Örneğin, bir plazada iyi bir statüde çalışan bir erkek ile fabrikada işçi olarak çalıșan bir erkeğin deneyimlediği aynı erkeklik değildir. Burdan yola çıkarak Sancar (2009), Türkiye'de erkekliğe dair yaptığı çalışmasında alt-sınıftan erkeklerin erkekliğin "aile reisliği" ideolojisine sıkı sıkıya sarıldıklarını göstermiştir. Aile reisliği statüsü Türkiye gibi ataerkil bir toplumda erkeğe mikro alanda eşine ve çocuklarına karşı baskınlığını gösterme firsatı vermekte; bu anlamda da diğer erkekliklerle (örn., patronlar) girdiği ilişkide kendisini ispatlayacak güvenli alanlar yaratmaktadır.

Benzer şekilde, bireyler cinsiyet rollerine, kalıpyargılarına ve sosyal kurallarına farklı seviyelerde uyum gösterebilirler. Sosyal kurallara uyum göstermeyenler çeşitli şekillerde cezalandırılır çünkü toplumsal sistem kendi devamlılığını garantiye alma çabasındadır (Jost ve Kay, 2005). Erkeklik açısından ele aldığımızda ise, erkeklik rolü beklentilerini karşılayamama durumu erkeklerin değersizlik, eksiklik, rahatsızlık, gerginlik ve stres hissetmesiyle sonuçlanabilir (örn., Levant, 1996; Pleck, 1981). Kendisinden beklenen cinsiyet rollerini yerine getirememe stresi yaşayan erkekler, geleneksel olarak erkeklik statüsünü garantileyen saldırganlık ve şiddet (Baugher ve Gazmarariyan, 2015) gibi ayrımc1 ve olumsuz davranışlarda bulunarak güç ve kontrol duygularını koruma eğilimine girebilirler (Eisler, 1995).

Gerek kalıpyargılar, gerek tutumlar, gerekse de erkeklik nomları bağlamında ele alınan tüm bu çalışmalar sınırlandırılmış bir erkeklik algısının varlığına işaret etmektedir. Toplumsal cinsiyeti icra etmenin çok farklı yolları ve dolayısıyla farklı erkeklikler mümkün olsa da bu algı, insanların düşünce ve davranışlarını geleneksel erkeklik ideallerine mecbur birakmakta ve bu ideallerin dışına çıkmaya çalıșanları cezalandırmaktadır. Örneğin, "erkek ev işi yapmaz" "çocuğa anne bakar" öğretilerine karşın ev işi yapmak ve çocuğuyla sosyal rolünün gerektirdiğinden fazla ilgilenmek isteyen bir erkek ikilem yaşayabilir. Erkeksi cinsiyet rolü stresi çalıșmaları (Eisler ve Skidmore, 1987), bu ikilemin erkeklerin hem birey- 
sel hayatlarında hem de ilişkisel hayatlarında ne kadar olumsuz sonuçlara varacağını bilimsel olarak göstermiştir. Erkeklik normları ve kalıpyargıları her ne kadar k1sıtlayıcı ve yargılayıcı olsa da, daha eşitlikçi bir toplum adına erkeklerin kendilerini de olumsuz yönde etkileyen bu normları sorgulamaları oldukça önemlidir.

Türkiye özelinde bu sorgulamayı yaratmak, fark11 mecralarda tartışmak ve genişletmekle mümkündür. Sosyal psikoloji yazınında son yıllarda ivme kazanan çalışmalar Türkiye'de erkek benliğinin oluşumu (Üstünel, 2010); kadına yönelik şiddetin erkeklik ideolojisi ve erkeklik tehdidi ile olan ilişkisi (Türkoğlu, 2013a); iş sahibi olmak ve işsizliğin erkekliğin inşasındaki rolü (Türkoğlu, 2013b); evli erkeklerin kültürel değişimle yaşadığ 1 içsel ve ilişkisel çelişkiler (Bolak-Boratav ve ark., 2014); namus ve erkeklik ideolojisinin erkek-erkeğe ilişkilerdeki rolü (Elgin, 2016) ve kırılgan erkeklik kuram1nın Türkiye kültüründe test edilmesi (Türkoğlu, 2018) gibi konulara odaklanarak erkekliği yapısal ve toplumsal olarak incelemektedir. Bu çalışmalardan yola çıkarak erkeksilik, erkeklik, erkek rol stresi gibi konuların detaylı incelenmesi ve bu konuların cinsiyetçi tutumlar, namus algısı, dindarlık, sosyo-ekonomik ve kültürel değişkenler ile ilişkisine bakılması Türkiye ortamında konunun daha net anlaşılmasına yardımcı olacaktır. Bunun yanı sıra, bu makalede tercihen ele alınmamıss olan erkeklik ve eşcinsellik arasındaki ilişkinin de çalışılması gereken bir konu olduğu görülmektedir. Türkiye açısından bakıldığında, Homofobi Indeksi (Hudson ve Ricketts, 1980) Sakallı-Uğurlu tarafından "Eşcinsellere ilişkin Tutumlar Ölçeği” olarak Türkçeye çevrilmiş ve birçok çalışmasında kullanılmıştır (Örn., Sakalllı, 2002; Türkiye'de yapılan bu çalışmalar için bkz. Sakallı-Uğurlu, 2006). Sakallı (2002) cinsiyetçilik düzeyindeki artış ile eşcinsellere ilişkin olumsuz tutumlar arasında korelasyon bulmuştur. Bu tür bulgular geleneksel toplumsal cinsiyet rollerini kabullenen kişilerin homofobi düzeylerinde artış olabileceğini göstermektedir. Ancak, Sakall1-Uğurlu önceki çalışmalarında erkeklere ilişkin tutumları doğrudan ölçmemiştir. Buna karşın, Sakallı-Uğurlu ve Uğurlu (2016) "Erkeklere ilişkin Çelişik Duygular Ölçeği”" (Glick ve Fiske, 1999) ile Herek'in (1988) Geylere ilişkin Tutumlar Ölçeği'ni kullanarak geylere ilişkin önyargı ile erkeklere ilişkin çelişik duygular arasında olumlu yönlü bir ilişki bulmuşlardır.

Ayrıca, güncel bir çalışmada Eslen-Ziya ve Koc (2016) eşcinsel erkeklerin hegemonik erkeklik algılarını ele almıştır. Bulgulara bakıldığında, eşcinsel erkeklerin heteronormatif hegemonik erkeklik ideallerini söylemsel olarak sürdürdükleri ve eşcinsel erkeklere yönelik içselleştirilmiş bir önyarg1 sahibi oldukları görülmektedir. Örneğin, ideal erkeği geleneksel erkeklik ideolojisinin sunduğu gibi duygularını belli etmeyen, cesur, risk ala- bilen, rekabetçi, başar1 ve statüyü önemseten ve erkeksi görünen erkek olarak resmetmişlerdir. Hemen her görüşmeci eşcinselliğini açıkça ifade eden eşcinsellere ve kadınsı tavırlar sergileyen eşcinsellere yönelik bir önyarg1 beslemektedir. Geleneksel erkeklik ideolojisinin hedefinde duran bir grup olarak eşcinsel erkeklerin kadınsı tavırlar sergileyen eşcinsellere yönelik önyargı sahibi olması ve hegemonik erkeklik ideallerini benimsemeleri ironik olsa da yazarlar erkekliklerin kültürel bağlamlara göre inşa edildiğini ve bu durumun da bir toplumda var olma stratejisi olabileceğini öne sürmektedir. Bu gibi çalışmaların Türkiye'de cinsel yönelim temelli azınlık grupların yaşadığ 1 toplumsal sorunlara 1şık tutacaktır.

Son olarak, cinsiyet kalıpyargıları, erkeksilik, erkeklik alg1sı ve ideolojilerinin toplumlarda yarattığ olumsuz çıktıların değiştirilebilmesi için yeni çalışmaların yapılması gerekli görülmektedir. Örneğin, erkek ve kadını tanımlayan özellikler olarak tanımlanan kalıpyargılarda değişiklik sağlanması için eğitim kurumlarında çalışmalar yapılabilir. İlkokul kitaplarında veya derslerinde toplumsal cinsiyet kalıpyargılarını, toplumsal cinsiyetçiliği ve erkeklik ideolojisini destekleyen ve meşrulaştıran resimler veya açıklamalar kullanılmayabilir. Kadın ve erkek rollerinde eşitliği sağlayacak değişim programları hazırlanabilir. Türkiye'de kadın ve erkek olmak ile ilgili kalıpyargılar anne ve babalık etrafinda şekillendiğinden (örn., Sakall1-Uğurlu ve ark., 2018b) daha eşitlikçi bir anne-babalığın inşa edilmesini hedefleyen programlara destekler arttırılabilir. Örneğin, Türkiye'de Anne Çocuk Eğitim Vakfi'nın (AÇEV) başlatmış olduğu "ilk iş babalık" projesi, baba-çocuk ilişkilerini iyileştirmeyi ve eşitlikçi aile yapısını desteklemeyi hedeflemektedir. $\mathrm{Bu}$ şekilde erkekliğin aile reisliğine ve duygu kısıtlamasına bağlı olmadığı ve iletişime daha açık erkekliklerin inşası amaçlanmaktadır (bkz. http:// ilkisbabalik.acev.org/). Erkeklerin çocuk bakımı ve aile içi eşitliği destekleyen bu gibi programların yanında, erkekliğin saldırganlık ve şiddet ile olan ilişkisini engellemeye yönelik yeni müdahale ve eğitim programları geliştirmek faydalı olacaktır. 


\section{Kaynaklar}

Abele, A. E. ve Wojciszke, B. (2007). Agency and communion from the perspective of self versus others. Journal of Personality and Social Psychology, 93, 751-763. doi:10.1037/0022-3514.93.5.751.

Addis, M. E. ve Schwab, J. R. (2013). Theory and research on gender are always precarious. Psychology of Men \& Masculinity, 14(2), 114-116. doi:10.1037/a0030960

Aktan, T. ve Bilim, G. (2016). Kadınlara yönelik kalıpyargıların içerikleri: Kalıpyargı İçeriği Modeli çerçevesinde bir inceleme. Nesne, 4(8), 147-182.

Ataca, B., Kağıtcıbaşı Ç. ve Diri, A. (2005). The Turkish family and the value of children: Trends over time. G. Trommsdorff ve B. Nauck (Ed.), The value of children in cross-cultural perspective: Case studies from eight societies içinde (91-119). Lengerich: Pabst Science Publishers.

Atay, T. (2004). "Erkeklik" en çok erkeği ezer. Toplum ve Bilim, 101, 11-30.

Baugher, A. R. ve Gazmararian, J. A. (2015). Masculine gender role stress and violence: A literature review and future directions. Aggression and Violent Behavior, 24, 107-112. doi:10.1016/j.avb.2015.04.002

Baykal, S. (1988). Üniversite ögrencilerinin cinsiyet roller ile kalıpyargılarının bazı değişkenler açısından incelenmesi. Yayınlanmamıs doktora tezi. Hacettepe Üniversitesi.

Beere, C.A., King, D.W., Beere, D.B. ve ark. (1984). The sex-role egalitarianism scale: A measure of attitudes toward equality between the sexes. Sex Roles, 10 (7-8), 563-576.

Bem, S. L. (1974). The measurement of psychological androgyny. Journal of Consulting and Clinical PSychology, 42, 155-162.

Berke, D. S., Reidy, D. E., Miller, J. D. ve Zeichner, A. (2016). Take it like a man: Gender-threatened men's experience of gender role discrepancy, emotion activation, and pain tolerance. Psychology of Men \& Masculinity. Advance online publication. http://dx.doi.org/10.1037/men0000036

Bernard, J., Bernard, S. ve Bernard, M. (1985). Courtship violence and sex-typing. Family Relations, 34, 573-576

Bolak- Boratav, H., Okman-Fișek, G. ve Ziya-Eslen, H. (2014). Unpacking masculinities in the context of social change: Internal complexities of the identities of married men in Turkey. Men and Masculinities, 17(3), 299-324. doi:10.1177/1097184X14539511

Bolak-Boratav, H., Okman-Fişek, G. ve Eslen-Ziya, H. (2017). Erkekliğin Türkiye halleri. İstanbul: İstanbul Bilgi Üniversitesi Yayınları.
Bosson, J. K., Prewitt-Freilino, J. L. ve Taylor, J. N. (2005). Role rigidity: A problem of identity misclassification? Journal of Personality and Social Psychology, 89(4), 552-565. doi:10.1037/00223514.89.4.552

Bosson, J. K. ve Vandello, J. A. (2011). Precarious manhood and its links to action and aggression. Current Directions in Psychological Science, 20(2), 82-86. doi:10.1177/0963721411402669

Bosson, J. K. ve Vandello, J. A. (2013). Manhood, womanhood, and the importance of context: A reply to comments. Psychology of Men \& Masculinity, $14,125-128$.

Bosson, J. K., Vandello, J., Burnaford, R. M., Weaver, J. R. ve Wasti, S. A. (2009). Precarious manhood and displays of physical aggression. Personality and Social Psychology Bulletin, 35(5), 623-634. doi:10.1177/0146167208331161

Brannon, R. (1976). The male sex role: Our culture's blueprint for manhood and what it's done for us lately. D. David ve R. Brannon (Ed.), The forty-nine percent majority: The male sex role içinde (1-49). Reading, MA: Addison-Wesley.

Brannon, R. ve Juni, S. (1984). A scale for measuring attitudes about masculinity. Psychological Documents, 14(1).

Brescoll, V. L., Uhlmann, E. L., Moss-Racusin, C. ve Sarnell, L. (2012). Masculinity, status, and subordination: Why working for a gender stereotype violator causes men to lose status. Journal of Experimental Social Psychology, 48(1), 354-357. doi:10.1016/j.jesp.2011.06.005

Bunting, A. B. ve Reeves, J. B. (1983) Perceived male sex orientation and beliefs about rape. Deviant Behavior,4, 281-295. doi:10.1080/01639625.1983.9967618

Burda, D. (2017). Dünyanın dört bir yanından ilk regl ritüelleri. Erişim tarihi: 12.06.2018, http://www.hurriyet.com.tr/kelebek/hayat/dunyanin-dort-bir-yanindan-ilk-regl-rituelleri-40524757.

Burgess, D. ve Borgida, E. (1999). Who women are, who women should be: Descriptive and prescriptive gender stereotyping in sex discrimination. $P S$ ychology, Public Policy, and Law, 5(3), 665-692. doi:10.1037/1076-8971.5.3.665

Cheryan, S., Cameron, J. S., Katagiri, Z. ve Monin, B. (2015). Manning up: Threatened men compensate by disavowing feminine preferences and embracing masculine attributes. Social Psychology, 46(4), 218-227. doi:10.1027/1864-9335/a000239

Chrisler, J. C. (2013). Womanhood is not as easy as it seems: Femininity requires both achievement and restraint. Psychology of Men \& Masculinity, 14(2), 117-120. doi:10.1037/a0031005 
Cohen, D. ve Vandello, J. A. (2001). Honor and "faking" honorability. R. Nesse (Ed.), Evolution and the capacity for commitment içinde (163-185). New York: Russell Sage.

Connell, R. W. (1995, 2005). Masculinities. Berkeley: University of California Press.

Connell, R. W. ve Messerschmidt, J. W. (2005). Hegemonic masculinity: Rethinking the concept. Gender and Society, 19,829-59.

Dahl, J., Vescio, T. K. ve Weaver, K. (2015). How threats to masculinity sequentially cause public discomfort, anger, and ideological dominance over women. Social Psychology, 46(4), 242-254. doi:10.1027/1864-9335/a000248

Deaux, K. ve Kite, M. E. (1993). Gender stereotypes. F. Denmark ve M. Paludi (Ed.), Handbook on the psychology of women içinde (107-139). Westpot, CT: Greenwood Press.

Dedeoğlu, S. (2000). Toplumsal cinsiyet roller açısından Türkiye'de aile ve kadın emeği. Toplum ve Bilim, 86, 139-170.

Doyle, J. D. ve Moore, R. J. (1978). Attitudes toward the male role scale: An objective instrument to measure attitudes toward the rights and roles of men in contemporary society. JSAS Catalog of Selected Documents in Psychology, 8, 35-36.

Dökmen, Z. (1991). Bem cinsiyet rolü envanteri kadınsıl1k ve erkeksilik ölçekleri Türkçe formunun psikometrik özellikleri. Kriz Dergisi, 7(1). 27-40.

Eagly, A. H. ve Steffen, V. J. (1984). Gender stereotypes stem from the distribution of women and men into social roles. Journal of Personality and Social Psychology, 466 (7), 35-754.

Eagly, A. H. ve Wood, W. (1982). Inferred sex differences in status as a determinant of gender stereotypes about social influence. Journal of Personality and Social Psychology, 43, 915-928.

Eisler, R. M. (1995). The relationship between masculine gender role stress and men's health risk: The validation of a construct. R. F. Levant ve W. S. Pollack (Ed.), A new psychology of men içinde (207-225). New York: Basic Books.

Eisler, R. M. ve Skidmore, J. R. (1987). Masculine gender role stress: Scale development and component factors in the appraisal of stressful situations. $\mathrm{Be}$ havior Modification, 11, 123-136.

Eisler, R.M., Skidmore, J. R. ve Ward, C. H. (1988). Masculine gender- role stress: Predictor of anger, anxiety, and health-risk behaviors. Journal of Personality Assessment, 52,133-141.

Elgin, V. M. (2016). Türkiye'de namus kültürünün incelenmesi: Namus, erkeklik ve erkek erkeğe hakarete karşı tepkiler. Yayımlanmamış doktora tezi. Orta
Doğu Teknik Üniversitesi, Ankara.

Ellis, L. J. ve Bentler, P. M. (1973). Traditional sex determined role standards and sex stereotypes. Journal of Personality and Social Psychology, 25, 28-34.

Eslen-Ziya, H. ve Koc, Y. (2016). Being a gay man in Turkey: Internalised sexual prejudice as a function of prevalent hegemonic masculinity perceptions. Culture, Health \& Sexuality, 18, 799-811. doi:10. 1080/13691058.2015.1133846

Fiske, S. T., Cuddy, A. J. C., Glick, P. ve Xu, J. (2002). A model of (often mixed) stereotype content: Competence and warmth respectively follow from perceived status and competition. Journal of Personality and Social Psychology, 82, 878-902.

Frederick, D. A., Shapiro, L. M., Williams, T. R., Seoane, C. M., McIntosh, R. T. ve Fischer, E. W. (2017). Precarious manhood and muscularity: Effects of threatening men's masculinity on reported strength and muscle dissatisfaction. Body Image, 22, 156165. doi:10.1016/j.bodyim.2017.07.002

Franchina, J. J., Eisler, R. M. ve Moore, T. M. (2001). Masculine gender role stress and intimate abuse: Effects of masculine gender relevance of dating situations and female threat on men's attributions and affective responses. Psychology of Men and Masculinity, 2, 34-41.

Gallagher, K. E. ve Parrott, D. J. (2011). What accounts for men's hostile attitudes toward women? The influence of hegemonic male role norms and masculine gender role stress. Violence Against Women, 17(5), 568-583. doi:10.1177/1077801211407296

Garnets, L. ve Pleck, J. H. (1979). Sex-role identity, androgyny, and sex-role transcendence: A sex role strain analysis. Psychology of Women Quarterly, 3, 270-283.

Gerdes Z. T., Alto K. M., Jadaszewski S., D'Auria F. ve Levant R. F. (2017). A content analysis of research on masculinity ideologies using all forms of the Male Role Norms Inventory (MRNI). Psychology of Men \& Masculinity (Advance online publication). Retrieved from http://dx.doi.org/10.1037/ men0000134

Gilmore, D. (1990). Manhood in the making. New Heaven, CT: Yale University Press.

Glick, P. ve Fiske, S. T. (1999). Ambivalence towards men inventory. Psychology of Women Quarterly, 23, 519-536. doi:10.1111/j.1471-6402.1999. tb00379.x

Glick, P., Sakallı-Uğurlu, N., Akbaş, G., Metin Orta, I. ve Ceylan, S. (2016). Why do women endorse honor beliefs? Ambivalent sexism and religiosity as predictors. Sex Roles, 75, 543-554. doi: 10.1007/ s11199-015-0550-5 
Glick, P., Lameiras, M., Fiske, S. T., Eckes, T., Masser, B., Volpato, C.,... Wells, R. (2004). Bad but bold: Ambivalent attitudes toward men predict gender inequality in 16 nations. Journal of Personality and Social Psychology, 86, 713-728. doi:10.1037/00223514.86.5.713

Good, G.E., Borst, T. S. ve Wallace, D.C. (1994). Masculinity research: A review and critique. Applied Preventive Psychology, 3, 3-14.

Good, G. E., Hepper, M. J., Hillenbrand-Gunn, T. ve Wang, L. (1995). Sexual and psychological violence: An exploratory study of predictors in college men. Journal of Men's Studies, 4, 59-71.

Good, G. E., Robertson, J. M., O’Neil, J. M., Fitzgerald, L. F., Stevens, M., DeBord, K., ve ark. (1995). Male gender role conflict: Psychometric issues and relations to psychological distress. Journal of Counseling Psychology, 42, 3-10.

Griffiths, S., Murray, S. B. ve Touyz, S. (2015). Extending the masculinity hypothesis: An investigation of gender role conformity, body dissatisfaction, and disordered eating in young heterosexual men. Psychology of Men \& Masculinity, 16(1), 108-114. doi:10.1037/a0035958

Herek, G. M. (1988). Heterosexuals' attitudes toward lesbians and gay men: Correlates and gender differences. Journal of Sex Research, 25, 451-477. doi:10.1080/00224498809551476.

Holmes, D. S. (1971). Compensation for ego threat: Two experiments. Journal of Personality and Social Psychology, 18, 234-237.

Hudson, W. ve Ricketts, W. (1980). A strategy for measurement of homophobis. Journal of Homosexuality, 5, 357-372.

Iazzo, A. (1983). The construction and validation of Attitudes Toward Men Scale. Psychological Record, 33, 371-378.

Jakupcak, M., Lisak, D. ve Roemer, L. (2002). The role of masculine ideology and masculine gender role stress in men's perpetration of relationship violence. Psychology of Men \& Masculinity, 3(2), 97106. doi:10.1037//1524-9220.3.2.97

Jenkins, S. S. ve Aube, J. (2002). Gender differences and gender-related constructs in dating aggression. Personality and Social Psychology Bulletin, 28, 1106-1118.

Jost, J. T. ve Kay, A. C. (2005). Exposure to benevolent sexism and complementary gender stereotypes: Consequences for specific and diffuse forms of system justification. Journal of Personality and Social Psychology, 88(3), 498-509. doi:10.1037/00223514.88.3.498

Kachel, S., Steffens, M. C. ve Niedlich, C. (2016).
Traditional masculinity and femininity: Validation of a new scale assessing gender roles. Frontiers in Psychology, 7, 956-975. doi:10.3389/ psyg.2016.00956.

Kalkan, M. ve Odac1, H. (2017). Endorsement of traditional male role norms and marital adjustment among Turkish men. Men and Masculinities, 20(2), 1-19. doi:10.1177/1097184X15625312

Kandiyoti, D. (1978). Kadınlarda psiko-sosyal değişim boyutları: Cinsiyet ve kuşaklar arası bir karşılaştırma. Yayınlanmamış doçentlik tezi. İstanbul: Boğaziçi Ünivesitesi.

Kırıml1, Y. (2010). Yetişkin olmaya ilk adım "sünnet". Ankara Üniversitesi Dil ve Tarih Coğrafya Fakültesi Antropoloji Dergisi, 24, 19-35.

Kosakowska-Berezecka, N., Besta, T., Adamska, K., Jaśkiewicz, M. ve Vandello, J. A. (2016). If my masculinity is threatened I won't support gender equality? The role of agentic self-stereotyping in relations. Psychology of Men \& Masculinity, 17(3), 274-284. doi: $10.1037 / \mathrm{men} 0000016$

Laws, J. L. (1979). The second X: Sex role and social role. New York: Elsevier.

Lease, S. H., Çiftçi, A., Demir, A. ve Boyraz, G. (2009). Structural validity of Turkish versions of the Gender Role Conflict Scale and Male Role Norms Scale. Psychology of Men \& Masculinity, 10(4), 273287. doi:10.1037/a0017044

Lease, S. H., Montes, S. H., Baggett, L. R., Sawyer, R. J., Fleming-Norwood, K. M., Hampton, A. B., ... Boyraz, G. (2013). A cross-cultural exploration of masculinity and relationships in men from Turkey, Norway, and the United States. Journal of Cross-Cultural Psychology, 44(1), 84-105. doi: $10.1177 / 0022022111432293$

Lenney, E. (1991). Sex roles: The measurement of masculinity, femininity, and androgyny. J. P. Robinson, P. R. Shaver ve L. S. Wrightsman (Eds.), Measures of personality and social psychological attitudes içinde (vol. 1, Ss. 573-660). San Diego, CA: Academic Press.

Leone, R. M., Parrott, D. J., Swartout, K. M. ve Tharp, A.T. (2016). Masculinity and bystander attitudes: Moderating effects of masculine gender role stress. Psychology of Violence, 6(1). 82-90.

Levant, R. F. (1996). The new psychology of men. Professional Psychology: Research and Practice, 27, 159-265.

Levant, R. F. (2011). Research in the psychology of men and masculinity using the gender role strain paradigm as a framework. American Psychologist, November, 765-776. doi:10.1037/a0015652

Levant, R. F., Gerdes, Z. T., Alto, K. M., Jadaszewski, 
S. E., Ryon, C., Levant, R. F., ... Mcdermott, R. C. (2017). Development and evaluation of the fathers' expectations about sons' masculinity scale (Short Form). Psychology of Men \& Masculinity, 19(3), 325-339. doi:10.1037/men0000108

Levant, R. F., Hall, R. J. ve Rankin, T. J. (2013). Male Role Norms Inventory-Short Form (MRNI-SF): Development, confirmatory factor analytic investigation of structure, and measurement invariance across gender. Journal of Counseling Psychology, 60(2), 228-238. doi:10.1037/a0031545

Levant, R. F., Hall, R. J., Weigold, I. K. ve McCurdy, E.R. (2016). Construct validity evidence for the Male Role Norms Inventory-Short Form: A structural equation modeling approach using the bifactor model. Journal of Counseling Psychology, 63, 534-542. doi:10.1037/cou0000171

Levant, R. F., Hirsch, L. S., Celentano, E., Cozza, T. M., Hill, S., MacEachern, M., Marty, N. ve Schnedeker, J. (1992). The male role: An investigation of contemporary norms. Journal of Mental Health Counseling, 14, 325-337.

Levant, R. F., Rankin, T. J., Williams, C. M., Hasan, N. T. ve Smalley, K. B. (2010). Evaluation of the factor structure and construct validity of scores on the Male Role Norms Inventory-Revised (MRNI-R). Psychology of Men \& Masculinity, 11(1), 25-37. doi:10.1037/a0017637

Levant, R., Smalley, K., Aupont, M., House, A., Richmond, K. ve Noronha, D. (2007). Initial validation of the Male Role Norms Inventory-Revised (MRNI-R). The Journal of Men's Studies, 15(1), 83100. doi:10.3149/jms. 1501.83

Lisco, C. G., Leone, R. M., Gallagher, K. E. ve Parrott, D. J. (2015). "Demonstrating masculinity" via intimate partner aggression: The moderating effect of heavy episodic drinking. Sex Roles, 73(1-2), 58-69. doi:10.1007/s11199-015-0500-2

Luyt, R. (2005). The Male Attitude Norms Inventory-II: A measure of masculinity ideology in South Africa. Men and Masculinities, 8, 208-229.

Luyt, R. (2018). Masculinities representations inventory (MRI, English version): A measure of gender (re)presentation. Journal of Men's Studies, 26(2), 157-183.

Maass, A., Cadinu, M., Guarnieri, G. ve Grasselli, A. (2003). Sexual harassment under social identity threat: The computer harassment paradigm. Journal of Personality and Social Psychology, 85, 853-870.

Mahalik, J. R., Locke, B. D., Ludlow, L., Mahalik, J. R., Locke, B. D., Ludlow, L. H., ... Freitas, G. (2003). Development of the Conformity to Masculine Norms Inventory. Psychology of Men \& Masculinity, 4(1), 2-25. doi:10.1037/1524-9220.4.1.3
Marrs, H. ve Sigler, E. A. (2012). Male academic performance in college: The possible role of study strategies. Psychology of Men \& Masculinity, 13(2), 227-241.

McCreary, D. R., Wong, F. Y., Wiener, W., Carpenter, K. M., Engle, A. ve Nelson, P. (1996). The relationship between masculine gender role stress and psychological adjustment: A question of construct validity? Sex Roles, 34(7-8), 507-516.

Michniewicz, K. S., Bosson, J. K., Lenes, J. G. ve Chen, J. I. (2015). Gender-atypical mental illness as male gender threat. American Journal of Men's Health, 10 (4), 306-317. doi:10.1177/1557988314567224

Moore, T. M. ve Stuart, G. L. (2005). A review of the literature on masculinity and partner violence. Psychology of Men \& Masculinity, 6(1), 46-61. doi:10.1037/1524-9220.6.1.46

Moore, T. M., Stuart, G. L., McNulty, J. K., Addis, M. E., Cordova, J. V. ve Temple, J. R. (2008). Domains of masculine gender role stress and intimate partner violence in a clinical sample of violent men. Psychology of Men and Masculinity, 9, 82-89.

Moreland, J. ve Van Tuinen, M. (1978). The attitude toward masculinity transcendence scale. Paper presented at the Department of Psychology, Ohio State University, Columbus.

Moss-Racusin, C. A., Phelan, J. E. ve Rudman, L. A. (2010). When men break the gender rules: Status incongruity and backlash against modest men. Psychology of Men \& Masculinity, 11(2), 140-151. doi:10.1037/a0018093

Neff, J. A., Prihoda, T. J. ve Hoppe, S. K. (1991). 'Machismo', self-esteem, education and high maximum drinking among anglo, black and Mexican-American male drinkers. Journal of Studies on Alcohol, 52, 458-63.

O'Connor, E. C., Ford, T. E. ve Banas, N. C. (2017). Restoring threatened masculinity: The appeal of sexist and anti-gay humor. Sex Roles, 77, 567-580. doi:10.1007/s11199-017-0761-z

O’Neil, J. M. (2008). Summarizing 25 years of research on men's gender role conflict using the Gender Role Conflict Scale: New research paradigms and clinical implications. The Counseling Psychologist, 36(3), 358-445. doi:10.1177/0011000008317057

O’Neil, J.M., Helms, B.J., Gable, R.K., David, L. ve Wrightsman, L.S. (1986). Gender role conflict scale: College men's fear of femininity. Sex Roles, 14, 335-350.

Parent, M. C., Kalenkoski, C. M. ve Cardella, E. (2018). Risky business: Precarious manhood and investment portfolio decisions. Psychology of Men \& Masculinity, 19(2), 195-202. doi:10.1037/ men0000089 
Parent, M. ve Moradi, B. (2009). Confirmatory factor analysis of the Conformity to Masculine Norms Inventory and development of the Conformity to Masculine Norms Inventory-46. Psychology of Men \& Masculinity, 10(3), 175-189. doi:10.1037/ a0015481

Pleck, J. H. (1981). The myth of masculinity. Boston: MIT Press.

Pleck, J. H. (1995). The gender role strain paradigm: An update. R. F. Levant ve W. S. Pollack (Ed.), A new psychology of men içinde (11-32). New York, NY, US: Basic Books.

Pleck, J. ve Sawyer, J. (1974). Men and masculinites. New York: Prentice-Hall.

Pleck, J. H., Sonenstein, F. L. ve Ku, L. C. (1993). Masculinity ideology: Its impact on adolescent males' heterosexual relationships. Journal of Social Issues, 49(3), 11-29.

Pleck, J. H., Sonenstein, F. L. ve Ku, L. C. (1994). Attitudes toward male roles: A discriminant validity analysis. Sex Roles, 30, 481-501.

Pratto, F., Stallworth, L. M. ve Sidanius, J. (1997). The gender gap: Differences in political attitudes and social dominance orientation. British Journal of Social Psychology, 36, 49-68.

Rosenkratz, R.S., Bee, H., Vogel, S. ve Broverman, I. (1968). Sex role stereotypes and self-concepts in college students. Journal of Consulting and Clinical Psychology, 32, 287-295.

Rudman, L. A. ve Fairchild, K. (2004). Reactions to counterstereotypic behavior: The role of backlash in cultural stereotype maintenance. Journal of Personality and Social Psychology, 87(2), 157-176. doi:10.1037/0022-3514.87.2.157

Rudman, L. A., Mescher, K. ve Moss-Racusin, C. A. (2012). Reactions to gender egalitarian men: Perceived feminization due to stigma-by-association. Group Processes and Intergroup Relations, 16(5), 572-599. doi:10.1177/1368430212461160

Rudman, L. A., Moss-Racusin, C. A., Phelan, J. E. ve Nauts, S. (2012). Status incongruity and backlash effects: Defending the gender hierarchy motivates prejudice against female leaders. Journal of Experimental Social Psychology, 48(1), 165-179. doi:10.1016/j.jesp.2011.10.008

Rudman, L. A. ve Phelan, J. E. (2008). Backlash effects for disconfirming gender stereotypes in organizations. Research in Organizational Behavior, 28, 6179. doi:10.1016/j.riob.2008.04.003

Sakalli, N. (2002). The relationship between sexism and attitudes toward homosexuality in a sample of Turkish college students. Journal of Homosexuality, 42, 53-63.
Sakallı-Uğurlu, N. (2002). Çelişik duygulu cinsiyetçilik ölçeği: Geçerlik ve güvenirlik çalışması. Türk Psikoloji Dergisi, 17(49), 47-58.

Sakallı-Uğurlu, N. (2006). Eşcinsellere ilişkin tutumlar: Türkiye'de yapılan görgül çalışmalar. Türk Psikoloji Yazılarl, 9(17), 53-69.

Sakall1-Uğurlu, N. (2008). Erkeklere İlişkin Çelişik Duygular Ölçeği'nin Türkçe'ye uyarlanması. Türk Psikoloji Yazllarl, 11(21), 1-11.

Sakall1-Uğurlu, N. (2018). Sosyal psikolojide tutumlar ve tutum değişimi. Ankara: İmge Kitabevi.

Sakall1-Uğurlu, N., \& Akbaş, G. (2013). Namus kültürlerinde "namus" ve "namus adına kadına şiddet": Sosyal psikolojik açıklamalar. Türk Psikoloji Yazılarl , 16 (32), 76-91.

Sakallı-Uğurlu, N., \& Uğurlu, O. (2016). Predicting attitudes toward gay men with ambivalence toward men, questioning religion, and gender differences. Sex Roles, 74(5), 195-205. doi:10.1007/s11199015-0571-0

Sakall1-Uğurlu, N., Türkoğlu, B. ve Kuzlak, A. (2018a). Gender stereotypes in contemporary Turkey: What are the pictures of women and men? Nesne Psikoloji Dergisi, 6(13), 309-336. doi:10.7816/nesne-06-13-04

Sakallı-Uğurlu, N., Türkoğlu, B., Kuzlak, A. ve Gupta, A. (2018b). Stereotypes of single and married women and men in Turkish culture. Current Psychology doi:10.1007/s12144-018-9920-9

Sancar, S. (2009). Erkeklik: Imkansız iktidar, ailede, piyasada, sokakta erkekler. İstanbul: Metis Yayınlar1.

Saurer, M.K. ve Eisler, R.M. (1990). The role of masculine gender role stress in expressivity and social support network factors. Sex Roles, 23, 261-271.

Schmitt, M. T. ve Branscombe, N. R. (2001). The good, the bad, and the manly: Threats to one's prototypicality and evaluations of fellow in-group members. Journal of Experimental Social Psychology, 37(6), 510-517. doi:10.1006/jesp.2001.1476

Selek, P. (2008). Sürüne sürüne erkek olmak. İstanbul: İletişim Yayınları.

Smiler, A. P. (2004). Thirty years after the discovery of gender: Psychological concepts and measures of masculinity. Sex Roles, 50, 15-26.

Spence, J.T. ve Helmreich, R. L. (1978). Masculinity and femininty: Their psychological dimensions correlates and antecedents. Austin: University of Texas Press.

Spence, I. T., Helmreich. R. L. ve Holahan, C. T. (1979). Negative and positive components of psychological masculinity and femininity and their relationships to self-reports of neurotic and acting out behaviors. Journal of Personality and Social Psychology, 37, 1673-1682. 
Spence, J. T., Helmreich, R. L. ve Stapp, J. (1974). The Personal Attributes Questionnaire: A measure of sex role stereotypes and masculinity-femininity. Journal Supplement Abstract Service, American Psychological Association.

Spence, J. T., Helmreich, R. ve Stapp, J. (1975). Ratings of self and peers on sex role attributes and their relation to self-esteem and conceptions of masculinity and femininity. Journal of Personality and Social Psychology, 32(1), 29-39.

Swartout, K. M., Parrott, D. J., Cohn, A. M., Hagman, B. T. ve Gallagher, K. E. (2015). Abbreviated Masculine Gender Role Stress Scale. Psychological Assessment, 27(2), 489-500. doi:10.1037/t42717-000

Sünbüloğlu, N. Y. (2013). Erkek millet, asker millet: Türkiye'de militarizm, milliyetçilik ve erkeklik(ler). İstanbul: İletişim Yayınları.

Terborg, J. R. (1977). Women in management: A research review. Journal of Applied Psychology, 62, 647-664.

Thompson, E. H. (1990). Courtship violence and the male role. Men's Studies Review, 7, 3-13.

Thompson, E. H. ve Bennett, K. M. (2015). Measurement of masculinity ideologies: A (critical) review. Psychology of Men \& Masculinity, 16(2), 115-133. doi:10.1037/a0038609

Thompson, E. H., Grisanti, C. ve Pleck, J. H. (1985). Attitudes toward the male role and their correlates. Sex Roles, 13(7-8), 413-427. doi:10.1007/ BF00287952

Thompson, E. H. ve Pleck, J. H. (1986). The structure of male role norms. American Behavioral Scientist, 29, 531-543.

Thompson, E. H. ve Pleck, J. H. (1995). Masculinity ideologies: A review of research instrumentation on men and masculinities. R. F. Levant ve W. S. Pollack (Ed.), A new psychology of men içinde (129163). New York: Basic Books.

Thompson, E. H., Pleck, J. H. ve Ferrera, D. L. (1992). Men and masculinities: Scales for masculinity ideology and masculinity-related constructs. Sex Roles, 27(11-12), 573-604.

Türkoğlu, B. (2013a). Violence as a way of reconstructing manhood: The role of threatened manhood and masculine ideology on violence against women. Yayımlanmamış yüksek lisans tezi, Orta Doğu Teknik Üniversitesi.

Türkoğlu, B. (2013b). Fay hattında erkeklikler: Çalışma ve işsizlik ekseninde erkekliğe bakış. Mülkiye Dergisi, 37, 33-61.

Türkoğlu, B. (2019). Precarious manhood in Turkey: Earned, lost, and threatened status of manhood. Yayımlanmamış doktora tezi. Orta Doğu Teknik Üniversitesi, Ankara.
Twenge, J. M. (1997). Attitudes toward women, 19701995: A meta-analysis. Psychology of Women Quarterly, 21, 35-51. doi:10.1111/j .1471-6402.1997. tb00099.x

Üstünel, A. Ö. (2010). The construction of masculine self. Yayımlanmamış yüksek lisans tezi. Boğaziçi Üniversitesi.

Vandello, J. A. ve Bosson, J. K. (2013). Hard won and easily lost: A review and synthesis of theory and research on precarious manhood. Psychology of Men \& Masculinity, 14(2), 101-113. doi:10.1037/ a0029826

Vandello, J. A., Bosson, J. K., Cohen, D., Burnaford, R. M. ve Weaver, J. R. (2008). Precarious manhood. Journal of Personality \& Social Psychology, 95, 1325-1339. doi:10.1037/a0012453

Vandello, J. A., Cohen, D., Grandon, R. ve Franiuk, R. (2009). Stand by your man: indirect prescriptions for honorable violence and feminine loyalty in Canada, Chile, and the United States. Journal of Cross-Cultural Psychology, 40(1), 81-104. doi:10.1177/0022022108326194

Vandello, J. A., Hettinger, V. E., Bosson, J. K. ve Siddiqi, J. (2013). When equal isn't really equal: The masculine dilemma of seeking work flexibility. Journal of Social Issues, 69, 303-321.

Villemez, W. ve Toughey, J. C. (1977). A measure of individual differences in sex stereotyping and sex discrimination: The Macho scale. Psychological Reports, 41(2): 411-415.

Weaver, J. R., Vandello, J. A. ve Bosson, J. K. (2013). Intrepid, imprudent, or impetuous? The effects of gender threats on men's financial decisions. PSychology of Men \& Masculinity, 14(2), 184-191. doi:10.1037/a0027087

Weaver, J. R., Vandello, J. A., Bosson, J. K. ve Burnaford, R. M. (2010). The proof is in the punch: Gender differences in perceptions of action and aggression as components of manhood. Sex Roles, 62(3-4), 241-251. doi:10.1007/s11199-009-9713-6

Wester, S. R., Vogel, D. L., O’Neil, J. M. ve Danforth, L. (2012). Development and evaluation of the Gender Role Conflict Scale Short Form (GRCS-SF). Psychology of Men \& Masculinity, 13(2), 199-210. doi:10.1037/a0025550

Wester, S. R.,Vogel, D. L.,Wei, M. ve McLain, R. (2006). African American men, gender role conflict, and psychological stress: The role of racial identity. Journal of Counseling and Development, 84, 419-429.

Williams, J. E. ve Benetts, S. M. (1975). The definition of sex stereotypes via the adjective checklist. Sex Roles, 1, 327-337. 
White, A. M. (2002). Gender role conflict and racial identity as indicators of Black men's help seeking attitudes. Yayımlanmamış doktora tezi. Pennsylvania State University.

Whitley, R. B., Madson, M. B. ve Zeigler-Hill, V. (2018). Protective behavioral strategies and hazardous alcohol use among male college students: Conformity to male gender norms as a moderator. Psychology of Men \& Masculinity, 19(3), 477-483. http:// dx.doi.org/10.1037/men0000121

Worth, D. W, Matthews, P. A. ve Coleman, W. R. (1990). Sex role, group affiliation, family background, and courtship violence in college students. Journal of College Student Development, 31, 250-254.

Yousaf, O., Popat, A. ve Hunter, M. S. (2015). An investigation of masculinity attitudes, gender, and attitudes toward psychological help-seeking. Psychology of Men \& Masculinity, 16(2), 234-237. doi: $10.1037 / \mathrm{a} 0036241$

Zeybekoğlu, Ö. (2013). Günümüzde erkeklerin gözünden babalık ve aile. Mediterranean Journal of Humanities, 3(2), 297-297. doi:10.13114/ $\mathrm{MJH} / 201322486$ 


\section{Summary \\ To Be or Not to Be "Man": Masculinity/Manhood Studies from Social Psychological Perspective}

\author{
Nuray Sakallı \\ Middle East Technical University
}

The purpose of the current review is to present studies on masculinity, manhood, and masculine gender role stress under three main subtitles as (1) masculine gender stereotypes, (2) attitudes regarding masculinity, masculine gender norms, gender role stress, and precarious manhood, and (3) men's destructive behaviors toward themselves and others (e.g., gays and women) reflecting discrimination. Although the reviewed research mostly cover the studies on scale development (see Table 1), we also included many studies that used different methodologies such as in-depth interviews, correlational and experimental studies.

\footnotetext{
Masculine Gender Stereotypes

Literature on gender stereotypes suggests that women are defined with communal (i.e., caring for, relating with, and expressing oneself to others) whereas men are described with agentic goals (i.e., imposing oneself to others, aiming self-improvement, being confident and success-oriented) (e.g., Bem, 1974; Spence, Helmreich $\&$ Stapp, 1975). These stereotypes reflect descriptive, prescriptive and proscriptive social norms of being a man or a woman in a given society. They idealize men as career-oriented, aggressive, assertive, competitive, and excludes men who do not follow these stereotypes. Ideologically, enactment of these stereotypes maintains the existing gender system by putting men in a dominant and negating those who carry feminine stereotypes (Rudman et al., 2012), and by punishing men who don't coincide with prescriptive stereotypes (Brescoll et al., 2012). They also feed prejudice and discrimination in different ways. For example, men who define themselves with agentic stereotypes justify gender-based inequality and support traditional parenting roles more (Kosakowska-Berezecka et al., 2016). Similarly, men who told that they are not a stereotypical man perceive a threat and apply for sexist and homophobic jokes to reconstruct their manhood (O'Connor et al., 2017).
}

\author{
Beril Türkoğlu \\ Ankara Medipol University
}

Bem's groundbreaking research (1974), Bem's Sex Role Inventory, assesses the characteristics that people have in terms of communal and agentic stereotypes. Similarly, Spence et al. (1974) developed The Personal Attributes Questionnaires, including the desirable characteristics for men and women. All these stereotypical characteristics are representative of societal approval, thus, they justify backlash resulting from the transgression of these stereotypes. For example, people perceive men doing feminine tasks and being polite as gay or less competent for the task (Rudman \& Phelan, 2008).

\section{Masculinity Studies from the Perspective of Attitudes}

Stereotype research mostly focuses on masculine characteristics and attributions while attitude research focuses on the underlying factors of masculinity ideology and people's endorsement of this ideology; reflecting two different approaches: trait and normative approach. Trait approach defines people's gender standing in terms of having stereotypical characteristics. A man, for example, differentiates himself from other men and women as he avoids stereotypically feminine traits. The normative approach, on the other hand, works hand in hand with the ideological purpose of prescriptive/proscriptive stereotypes in a restrictive manner. Masculinity reflects a cultural ideology that shapes gender relations rather than psychological or biological characteristics (Thompson \& Pleck, 1995). Masculinity ideology expects men to satisfy the expectations of idealized men (i.e., hegemonic masculinity). It is not people's definitions of themselves as a man; rather, it is a definition of society about an idealized man, and to what extent people internalize and apply this definition in their relations (Pleck et al.,1993; Thompson et al.,1992).

Since the 1970s, research has uncovered the underlying factors of masculinity with different approaches such as stereotypes, norms, and ideologies etc. (Smiler, 2004). Table 1 presents the most important attitude

Address for Correspondence: Prof. Dr. Nuray Sakall, Middle East Technical University, Faculty of Arts and Sciences, Department of Psychology, Üniversiteler Mahallesi, Dumlupınar Bulvarı No:1 06800 Çankaya / Ankara

E-mail: nurays@metu.edu.tr 
scales which define the underlying factors of masculinity (ideology) as status and success (success, career, resource management etc.), toughness (tolerance to discomfort, self-restriction, emotional detachment, physical power etc.), avoidance of femininity (avoiding feminine activities, degrading feminine, objectifying women etc.), acceptance of patriarchal assumptions, fear and hatred of homosexuality, self-confidence, aggressiveness, attitudes towards sexuality, and emotional restriction.

\section{Studies on masculine gender role stress and strain}

Researchers have suggested that masculinity ideology may lead men to experience gender role stress or strain when they don't obey gender role norms. O'Neil et al. (1986) argue that gender role conflict exists on success/power/competition, fear of homosexuality, restrictive emotionality, restrictive affectionate behavior between men, and conflict between work and family. According to the normative approach, the social construction of masculine selves is also shaped by negative experiences during the socialization process and this makes way for a feeling of discomfort/stress (Pleck, 1995). Transgression of gender norms creates individual or interpersonal conflict and prevents other forms of self-actualizations than the socially accepted ones. The stress / strain / conflict that a man would feel may change in terms of men's social context and their endorsement of masculinity ideology (O'Neil, 2008). The masculine gender role stress may be relevant to various issues such as physical inadequacy, emotional restriction, subordination to women, and intellectual inferiority (Eisler \& Skidmore, 1987).

\section{Precarious manhood}

Pleck (1995) suggested that boys grow into men by learning that they should prove themselves to others while there are no such norms for girls growing into women. Similarly, Vandello et al. (2008) argued that people see manhood more of social status than womanhood. A man should earn his status and protect it via different social enactments. Once he loses it in the eyes of others, he needs to reaffirm this status by holding any "manly" (e.g., aggression, violence, toughness). Vandello \& Bosson (2013) called this hardly-won, easily lost status as precarious manhood. They have experimentally studied precarious manhood for the first time by creating gender a threat in various ways. For example, they apply gender-knowledge test where people test men's gender-stereotypical knowledge and say that their score is close to feminine identity (Vandello et al., 2008); make men use flowery-feminine hand lotion (Weaver et al., 2013) or make them braid hair of a baby doll in front of others (Bosson et al., 2009). Men who took a gender threat re- veal more aggressive (Vandello et al., 2008) and violent behavior (Bosson et al., 2009; Weaver et al., 2010) as well as making risky financial decisions (Weaver et al., 2013). Research on precarious manhood depicts that men are socially prone to perceive a gender threat easily and they experience manhood crisis while trying to get their lost social status back (Bosson \& Vandello, 2011).

\section{Destructive Outcomes of Masculinity/Manhood Reflecting Discrimination}

Many men experience psychological, physical and intergroup problems as they are restricted by masculinity ideology. In general, these problems can be classified under two subtitles as individual and interpersonal/intergroup problems.

At the individual level, men may experience many problems if they transgress masculinity norms and prescriptive stereotypes. For example, men are not satisfied with their muscles (Frederick et al., 2017), have eating disorders and complain about their body fat (Griffiths et al., 2015) as they conform to hegemonic masculinity ideals (Parent \& Moradi, 2009). They also refrain from some positive health behaviors such as healthy diet and exercises (Eisler et al., 1988) or using condoms in sexual relations (Pleck et al., 1993) as they feel high levels of gender role stress (Eisler \& Skidmore, 1987). In addition, the more they experience gender role conflict, the more they are afraid of being close to others (Good et al., 1995), the more likely to have psychological problems such as depression, high anxiety, and low self-esteem (O’Neil, 2008). The same masculinity ideologies may create a barrier to psychological help-seeking among men (Yousaf et al., 2015). Instead, they may increase their alcohol consumption as they face gender role stress (Whitley et al., 2018).

At the interpersonal/intergroup level, endorsement of masculinity ideology (Thompson \& Pleck, 1986) may lead many discriminatory behaviors against women and gay men such as increased violence towards partner (Moore et al., 2008) or fear of homosexuality (Thompson et al., 1985). In short, men try to protect their social status in the case of threat and stress via direct tools such as violence (Lisco et al., 2015) or indirect tools such as protecting male-dominant gender system in the society (Kosakowska-Berezecka et al., 2016).

\section{Masculinity/Manhood Studies in Turkey}

A few researchers have studied gender stereotypes in Turkey. Kandiyoti (1978) developed Gender Roles Stereotypes Scale (e.g., emotionality, self-sacrificing, toughness, assertiveness). Baykal (1988) examined the relationship between gender stereotypes and self-acceptance. Dökmen (1991) translated Bem's sex role inven- 
tory into Turkish. The most recent study about stereotypes reflects more emic and current values about being a man/woman that people stereotype men mostly as jealous, strong, selfish, emotional, ambitious, angry etc. (Sakall1-Uğurlu et al., 2018a). Considering the importance of marriage in Turkish culture, Sakallı-Uğurlu et al. (2018b) presented that college students describe married men with their gender roles such as being a father, breadwinner, responsible, hard-working, self-sacrificing and protecting family. They define single men only with their appearance and characteristics such as being a playboy or irresponsible. In general, Turkish men are perceived as dominant, masculine, and independent.

Qualitative research on the issue reveals that the concept of multiple masculinities is prevalent in Turkey. For example, men from different geographical areas (Üstünel, 2017) and socio-economic status (Bolak-Boratav, 2014) construct and perform their masculinity differently. Despite this plurality, the hegemonic masculinity is still defined as being a breadwinner, responsible, and working fathers (Sancar, 2009; Türkoğlu, 2013b).

There are also other studies exploring the societal touchstones of masculinity. Accordingly, the most important touchstones to be entitled as "a real man" in Turkey are being circumcised (Kirıml1, 2010), the first sexual experience (Selek, 2008), having military duty (Sünbüloğlu, 2013), starting a family and being a breadwinner (Türkoğlu, 2013), being a father (Zeybekoğlu, 2013), and having a baby boy (Ataca et al., 2008). Although the literature confirms socially-constructed and precarious nature of manhood, a recent study (Bolak-Boratav et al., 2017) found that men from different regions of Turkey defined being a man as they always felt like "they are a man." The result evokes a question that "whether manhood is a precarious status in Turkey or not?". Türkoğlu (2019) answers this by replicating precarious manhood studies in Turkey. She found that manhood is seen as an achieved social status compared to womanhood. However, both (manhood and womanhood) can be lost in cases of culture-specific gender threats.

Looking at the scale construction studies, we see that Turkish men also endorse masculinity glorifying status, avoiding femininity and being a tough man (Lease et al., 2009). Besides, they feel a conflict between holding power/status, hiding their emotions, and family relations. The more they endorse these ideologies, the less they invest in their romantic relations (Lease et al., 2013) and so their marriage quality decreases (Kalkan \& Odac1, 2017).

\section{Conclusion and Suggestions}

We reviewed research on masculine gender stereotypes, attitudes related to masculinity ideology, precari- ous manhood, and the destructive outcomes of masculinity ideology. We draw a picture of how research on masculinity, masculinity ideology and manhood can be examined in the field of social psychology. Both trait and normative approaches were presented. Traits approach conceptualizes masculinity as a personality characteristic. Normative approaches include ideological endorsements and practices (e.g., Smiler, 2004). Attitude research shows that traditional/hegemonic type of masculinity is still defined as having status and power, avoidance of femininity and emotionality, and being tough (Levant et al., 2010; Mahalik et al., 2003). In addition, research conducted in Turkey adds the importance of being a father and breadwinner and carrying responsibility for hegemonic Turkish masculinity (Bolak-Boratav et al., 2017; Sakallı-Uğurlu et al., 2018a).

Idealized masculinity may also create stress and strain when a man falls short of these gender roles. Men may feel stressed when they feel subordinated to women, intellectually inferior to others, physically inadequate (Eisler \& Skidmore, 1987), and this may lead to some physical (Griffiths et al., 2015) and psychological (Wester et al., 2006) health problems as well as prejudiced attitudes and discriminatory behaviors towards outgroups (e.g., women, gay men) (Baugher \& Gazmararian, 2015). It seems that we need more research focusing on the masculinity/manhood codes/norms and the possibility of changing these norms in order to create more egalitarian life for all genders. Further, supporting social policies targeting violence-free masculinity would be beneficial to improve the existing discriminatory gender system in Turkey. 